\title{
Danske herrnhuteres nationale kamp efter 1864
}

\author{
Af Andreas Øster.
}

De papirer, som i det følgende skal meddeles, bringer næppe nye oplysninger om den almindelige nationale kamp i Sønderjylland under tyskervældet, men de kan måske give et billede af de danskes kår et bestemt sted, hvor forholdene blev mere end almindeligt indviklede, fordi nationale og religiøse forhold kunne komme i konflikt med hinanden: herrnhuterkolonien Christiansfeld.

Hovedparten af disse papirer har ligget upåagtet hen i privateje i 100 år, og det er nxrmest ved en tilfældighed, at de nu er blevet opdaget som en slags historisk kildemateriale.

For at give dem den rette baggrund skal dog Christiansfelds udvikling forud for 1864 ganske kort skitseres.

Oprindeligt var Christiansfeld så godt som rent tysk. Struensee hidkaldte herrnhuterne fra Tyskland. Hverken deres nationalitet eller deres religiøse egenart betød noget for ham, men han havde brug for deres praktiske dygtighed $\mathrm{i}$ håndværk, industri og handel. Enkelte danske, som allerede tidligere havde sluttet sig til herrnhuterne, flyttede med det samme til den nye koloni, men endnu 25 år efter Christiansfelds grundlæggelse viser en mandtalsliste fra året 1797, at af 81 fastboende gifte menighedsmedlemmer var 43 født udenfor Danmark. På den tid har den danske tilflytning dog allerede gjort sig grldende, og dette forhold har forstærket sig i de folgende årtier.

Herrnhuterne havde blandt andre privilegier fået ret til at bruge tysk kirke- og skolesprog. Det har dengang dog ikke haft nationale grunde. Nationalitetsprincippet stammer først fra en senere tid. Derimod ønskede brødremenigheden af religiøse grunde at besætte 
de ledende stillinger i menigheden, særlig præstens, forstanderens og lærernes, med folk fra deres egne tyske uddannelsesinstitutter og det herrnhutiske miljø i Tyskland. Heller ikke de danske tilflyttere tog anstød af dette forhold. Den eneste ulempe, det førte med sig, var nødvendigheden af at tilegne sig et nødtørftigt kendskab til det tyske sprog.

Forst omkring 1840 begyndte de nationale modsætninger at vise sig. Enkelte danske, som salmedigteren Niels Johannes Holm, så skeptisk på dette fænomen, som de frygtede ville forstyrre troslivet. Men den historiske udvikling lod sig ikke standse, og efterhånden var majoriteten af almuen dansksindet, endog en del borgere af tysk xt havde slået så dybe rødder i den danske jord, at de følte sig som danske.

Selvfølgelig var der også dem, der holdt fast ved deres tyske nationalitet, og nogle af de danske tilflyttere overtog vel også sammen med de religiøse impulser tysk tænkemåde. Særligt var menighedens tjenestemænd, der var af tysk afstamning og som regel kun opholdt sig en kortere årrække i Christiansfeld, tysksindede, og også deres nationalitetsbevidsthed var, ikke mindst efter Napoleonskrigene, vokset i styrke.

Tiden mellem 1850 og 1864 har utvivlsomt skærpet den nationale modsætning, men $\mathrm{i}$ al almindelighed synes det religiøse fællesskab dog at have overskygget de to parters nationalisme, indtil nederlaget for Danmark kom med våbenstilstanden i Christiansfelds "Gemeinlogis « og Sønderjylland snart efter ved Wiener-freden kom under tysk herredømme. I nogle tilf $x$ lde, hvor danske patrioter lod deres følelser løbe af med sig, reagerede både de verdslige myndigheder og brødremenighedens ledelse på en hårdhændet måde, der varslede ilde. For alvor blussede striden i Christiansfeld dog først op, da de tyske embedsmænd greb ind $\mathrm{i}$ menighedens religiøse forhold.

\section{Aastrup-sagen. ${ }^{1}$}

I Christiansfeld virkede foruden den tyske præst Garve' også en dansk prædikant ved navn Aastrup, som afholdt regelmæssige danske gudstjenester for de religiøst vågne fra omegnen. Han var kendt for at være dansksindet, men han får, endog af tyskerne i byen, det vidnesbyrd, at han afholdt sig fra al deltagelse $\mathrm{i}$ aktiv politik.

Nogle mindre politiske sammenstød i Christiansfeld gav nu an- 


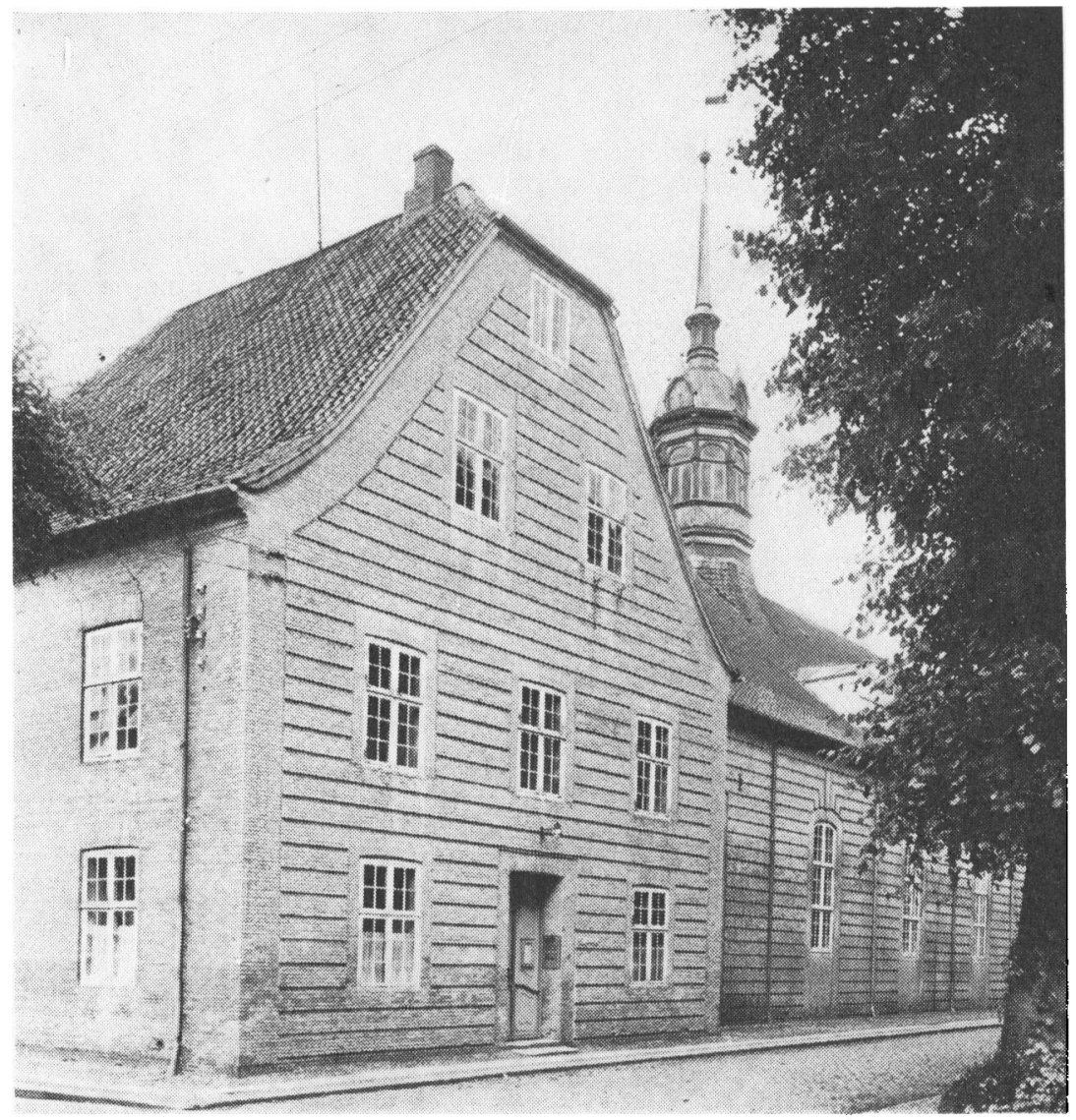

„Salen“, hvor brodremenighedens gudstjenester blev holdt.

ledning til, at herredsfogeden i Tyrstrup, Andersen, $i$ et brev til Garve forlangte, at denne skulle afskedige Aastrup for tyskfjendtlig virksomhed. Dette lå udenfor Garves kompetence, da Aastrup, ligesom Garve selv, var ansat af brødremenighedens centralledelse i Berthelsdorf ved Herrnhut, U. A. C. (Unitäts Aeltesten Conferenz). ${ }^{4}$ Garve sendte derfor brevet videre til Berthelsdorf.

Normalt skulle han forst have fremlagt sagen for det lokale nævn »Aeltesten Conferenz « i Christiansfeld, men da Aastrup havde sæde i denne korporation, undlod han det, hvad man næppe kan be- 
brejde ham. . Derimod vil man nok finde det mistænkeligt, at Garve hverken indberettede noget om Aastrups tilbageholdenhed overfor politiske spørgsmål eller gjorde U. A. C. opmærksom på, at herredsfogeden aldeles ingen ret havde til at stille krav om Aastrups afskedigelse.

Sagens forløb vil fremgå af det følgende resumé, som under 14. juli 1865 fra dansk side blev indsendt til Civilkommissionen i Slesvig. Det lyder (i oversættelse):

„Til de bøje civilkommisserer for hertugdømmet Slesvig.

Herved tillader undertegnede sig at fremstille forløbet ved afsættelsen af herværende danske præst, pastor Aastrup, for de høje herrer civilkommissærer.

I begyndelsen af december 1864 blev der overleveret til herværende tyske præst, pastor Garve, en skrivelse, $i$ hvilken den davæ rende herredsfoged Andersen indtrængende opfordrede brødremenighedens direktion i Berthelsdorf til at fjerne den danske præst $\mathrm{i}$ Christiansfeld, pastor Aastrup. Denne opfordring, ligesom hele skrivelsens tone, fik nævnte direktion til at antage, at herredsfogeden handlede efter ordre fra landsregeringen, og derfor blev pastor Aastrup omgående afsat fra sit embede. $\mathrm{Da}$ dette skridt imidlertid vakte stor opsigt og harme $\mathrm{i}$ hervarende menighed, eftersom man vidste, at pastor Aastrup aldrig havde givet sig af med politisk virksomhed, men som en begavet og trofast prædikant var til stor opbyggelse, besluttede den herværende menighed at sende en deputation til vor direktion $\mathrm{i}$ Berthelsdorf for at foranledige denne til at tilbagekalde afsættelsen. Direktionen ville gerne opfylde dette ønske, men var $\mathrm{i}$ den grad hildet $\mathrm{i}$ forestillingen om, at herredsfogeden havde handlet efter den højeste øvrigheds instruks, at den først ved en skrivelse til amtmanden ville underrette sig om betydningen af herredsfogedens skrivelse. Efter at have fået svar afsendte direktionen et udførligt promemoria, for at dette skulle fremlægges for amtmanden og ved denne (om fornødent) for de høje civilkommissærer. Direktionen erklærede $\mathrm{i}$ dette dokument tydeligt, at den ønskede at genindsætte pastor Aastrup $i$ hans embede, og bad øvrigheden ikke lægge noget $\mathrm{i}$ vejen for opfyldelsen af dette ønske.

I mellemtiden havde pastor Aastrup ved et personligt besøg i Flensborg søgt at erfare de høje civilkommissærers og i særdeleshed 


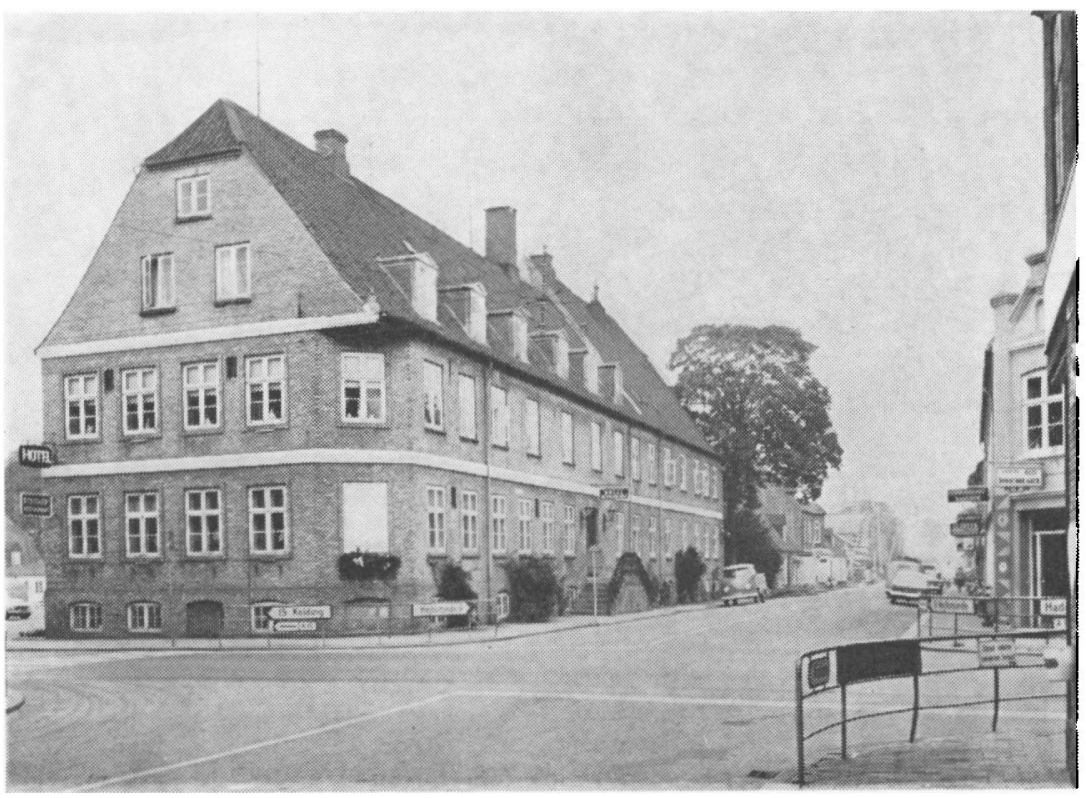

„Gemeinlogis“, gastgivergården. Bag hjornevinduerne på forste sal ligger det varelse, hvor våbenstilstanden blev sluttet (se side 120).

hans excellence, herr præsident, friherre von Zedlitz' mening. Hans excellence forsikrede, at hvis det var direktionens onske at genindsætte pastor Aastrup $\mathrm{i}$ hans embede, kunne ingen øvrighed forhindre det, og $\mathrm{i}$ særdeleshed kunne amtmanden ikke tage et sådant skridt uden civilkommissærernes tilladelse.

Alligevel mente amtmand $\mathrm{Kjer}$ sig berettiget til på egen hånd at besvare nævnte promemoria med et afslag, idet han nøjedes med at anføre, at han ikke havde fundet anledning til at indberette derom til civilkommissærerne. Dette ligesom de tidligere ytringer af amtmanden mod pastor Aastrup, at hvis han havde været en umoralsk eller udygtig prædikant, kunne han godt være blevet i sit embede, men jo mere nidkær og trofast en præst med danske sympatier var, desto farligere var han for deres sag, som bestod $i$ at gøre alt tysk, alt dette viser tydeligt, hvor sand amtmandens udtalelse er, at der for tiden ingen absolut retfærdighed er at opnå for pastor Aastrup. $\mathrm{Da}$ vi håber, at der nu findes retfærdighed for alle, har vi ikke 
villet undlade sandfærdigt at fremstille forløbet af denne sag i korthed, idet vi anbefaler den til de høje civilkommissærer på bedste måde.

Christiansfeld, 14. juli 1865.

A. Øster, borger og rebslagermester.

S. Lauersen, købmand.«

Der var gået 7 måneder siden herredsfoged Andersens krav om Aastrups afsættelse, inden de dansksindede borgere i Christiansfeld henvendte sig til Civilkommissionen, altså den verdslige øvrighed. Indtil da havde de søgt at holde striden indenfor brødremenighedens egne rammer. Ordføreren for den i resuméet nævnte deputation var Sigmund Christoph, hvis slægt for resten stammede fra Herrnhut. Han overbragte kort før jul 1864 direktionen følgende skrivelse (i overs $x$ ttelse):

"Med dyb sorg har den største del af herværende menighed erfaret, at vor kxre broder Joseph Aastrup er blever afsat fra sit embede som dansk præst her på stedet. $\mathrm{Da}$ hans virksomhed ret øjensynligt har været ledsaget af Herrens velsignelse, hvad også det talrige besøg til hans prædikener udadtil vidner om, beklager vi denne afsættelse også for Guds riges skyld, der skulle udbredes blandt vore naboer. Endnu meget mere smerteligt er det imidlertid, når vi erfarer, hvilke grunde der bliver anført for afsættelsen. Vi undertegnede kan med sandhed bevidne, at broder J. Aastrup aldrig har beskæftigct sig med politik $i$ sine prædikener eller blot hentydet til den, men altid har forkyndt evangeliet rent efter den brødrekirken forlenede indsigt. Han har altid været lydig og underdanig overfor øvrigheden. Vor kære broder Aastrups prædikener gik kun ud på synd og nåde og har for mange sjæle $\mathrm{i}$ og udenfor menigheden været til stor velsignelse.

Kære brødre! Vi er bange for, at dette skridt vil fore til vor herværende menigheds ruin. Vi er bange for, at I har ladet jer vildlede af en skrivelse, som var fremkaldt af partisk ånd og misundelse." Vort ønske og vor bøn er derfor, at I, kære brødre, vil sende en broder af jeres midte hertil, for at han kan overtyde sig om sandheden af nærværende skrivelse. Et sådant besøg ville også i høj grad tjene til at berolige gemytterne. For vi har den tillid til jer, kære 


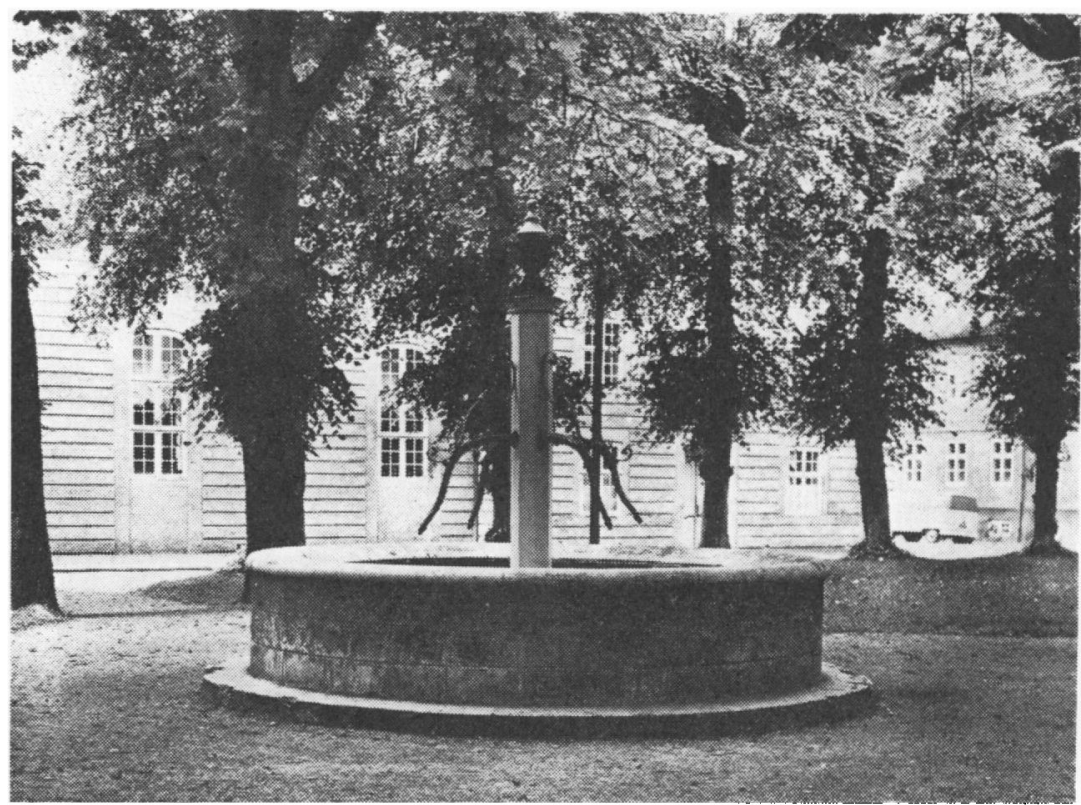

Pladsen med den typiske brond, koloniens centrum foran ,Salen“.

brødre af U. A. C., at det for jer gælder om at udbrede Guds rige, og at I ikke vil afsætte en kær broder, der står $\mathrm{i}$ en overordentlig velsignet virksomhed, på grund af usande beskyldninger.

Vi anbefaler også vor kære broder Christoph, som handler $\mathrm{i}$ vort navn, til de kære brødre af U. A. C.s velvilje og beder, at I vil høre på ham.

Til de kare brødre af Unitäts Aeltesten Conferenz $i$ Berthelsdorf.*

Skrivelsen er som det ses rettet til U. A. C. (Unitäts Aeltesten Conferenz), hele herrnhutismens overste ledelse, der fungerede som en slags ministerium og bl. a. ansatte de enkelte menigheders tjenestemænd. De enkelte menigheder blev ledet af en Aeltesten Conferenz, udnævint af U. A. C., under den tyske præsts forsæde og et "Aufseher Collegium, « valgt af menigheden, hvor menighedsforstanderen var formand. Deres funktioner svarede i nogen grad henholdsvis til menighedsrådets og sognerådets, dog at Aeltesten Conferenz havde betydelig større myndighed. Aeltesten Conferenz i 
Christiansfeld var udpræget tysksindet, medens danskerne havde noget større indflydelse $\mathrm{i}$ "Aufseher Collegium «. Klager over disse lokale institutioner kunne kun rettes til U. A. C. I denne havde hver enkelt menighed sin "decernent «, der skulle tage sig af vedkommende menigheds særlige forhold. Decernenten for Christiansfeld var dengang en mand ved navn Tietzen.

Christophs rejse og de danskes skriftlige henvendelse til direktionen i Berthelsdorf havde til følge, at U. A. C. blev betænkelig ved den forhastede måde, hvorpå den havde behandlet Aastrups sag.' Tietzen sendte som styrelsens representant et brev til Garve, hvori han pålagde denne, at han skulle ansøge amtmanden om sammen med forstander Jacobsen og inspektør von Bülow at måtte mødes med ham for at få nærmere oplysninger om, hvorvidt herredsfoged Andersen havde krævet Aastrups afsættelse på eget initiativ eller efter ordre fra de kompetente myndigheder. Derpå skrev Garve følgende brev til amtmand Kjer (i oversættelse):

\section{* Højvelbairne herre, bøjterede br. amtmand!}

Om aftenen den 10. december modtog jeg på embeds vegne fra Tyrstrup herredsfoged medfølgende skrivelse af 9. december, som jeg straks den følgende dag fremsendte til Unitäts Aeltesten Conferenz i Berthelsdorf ved Herrnhut.

Derpå modtog den herværende danske prædikant Aastrup den 19. december en skrivelse fra Unitäts Aeltesten Conferenz, ifølge hvilken han skulle søge sin afsked eller imødese sin afskedigelse, dog at han for at undgå demonstrationer ikke mere skulle optræde offentligt.

$\mathrm{Da}$ affattede nu hans venner, for at opnå genkaldelsen af dette skridt, en adresse til Unitäts Aeltesten Conferenz, med hvilken snedkermester Christoph den 21. december rejste til Herrnhut. Da herredsfogeden, hr. J. R. Andersen, i mellemtiden så uventet hurtigt var død, er der overfor Unitäts Aeltesten Conferenz blevet gjort gxldende, at han ved affattelsen af sin skrivelse måske allerede havde befundet sig $i$ en sygelig tilstand af irritation, og at skrivelsen vel ikke har været affattet efter ordre eller $i$ overensstemmelse med regeringen.

Derfor er det nu ved skrivelse af 24 . december blevet pålagt mig at tilstille Dem, hr. amtmand, den sal. herredsfogeds skrivelse til 


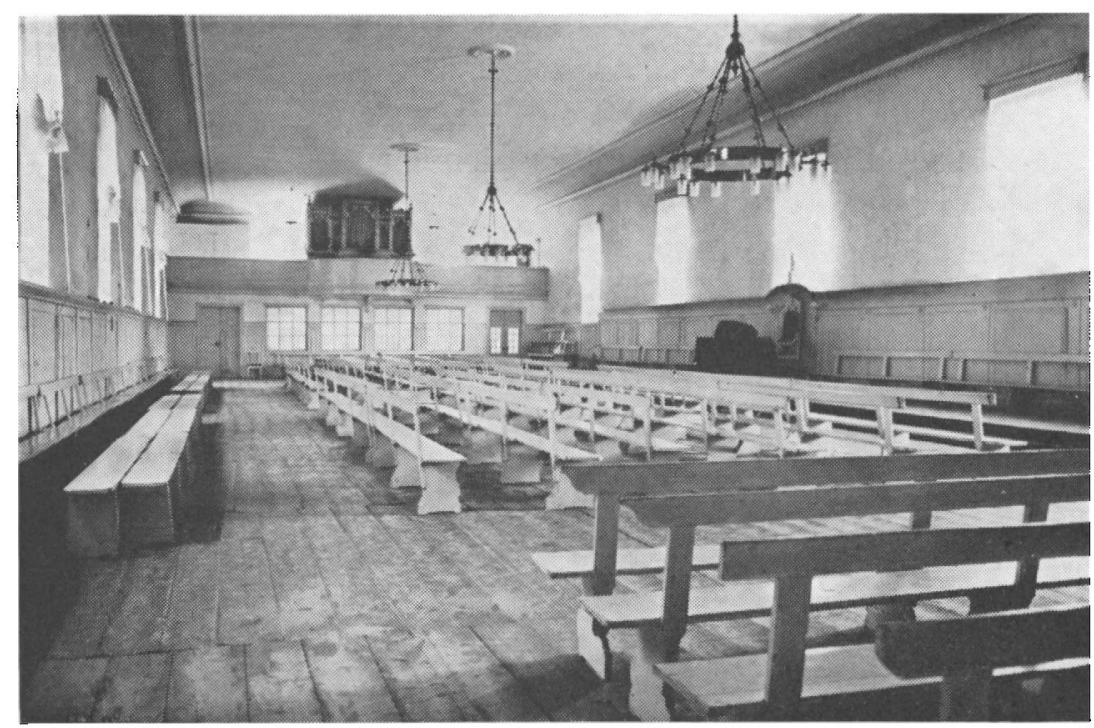

„Salen“ indvendig. Her virkede Austrup som dansk predikant.

gennemsyn med anmodning om snarest muligt at måtte komme til Dem sammen med forstander Jacobsen og inspektør von Bülow og modtage Deres personlige erklæring om, hvorvidt hin skrivelse skal betragtes som affattet $\mathrm{i}$ regeringens ånd og behandles som sådan. En snarlig skriftlig erklæring ville Unitäts Aeltesten Conferenz finde endnu mere kærkommen og værdifuld.

Men desværre er min tid netop nu så stærkt optaget af embedspligter, at jeg $\mathrm{i}$ det mindste som forslag må tillade mig den bøn godhedsfuldt at modtage os (såfremt De ikke må afslå det) til det onskede møde næste torsdag, den 29. om formiddagen klokken 11.

Christiansfeld, den 27. december 1864.

Med højagtelse og ærbødigst

Garve, præst.«

Brevet viser umiskendeligt Garves engagement på tyskernes side. Der er nxppe noget at sige til hans personlige sympatier $i$ den retning, da han var tysker, der kun tilfældigt og på begrænset tid var ansat $\mathrm{i}$ Christiansfeld. Men $\mathrm{i}$ hans ledende stilling indenfor menigheden kunne man nok have ventet en større neutralitet, hvor han 
talte som Christiansfelds officielle representant. Det var netop det, de danske menighedsmedlemmer savnede hos ham.

I sit brev til amtmand Kjer omtaler han, at herredsfoged Andersen, ophavsmanden til hele affæren, pludselig er død. Hans efterfølger blev en dreven jurist ved navn Selig.

Mødet mellem amtmanden og de tre mænd fra Christiansfeld kom i stand den 29. december 1864. Om dets forløb er der ikke andet bekendt, end at amtmanden tog meget venligt imod deputationen samt - hvad man kan slutte sig til ud fra tonen i Garves brev og amtmandens ved mødet lovede skriftlige svar, som han afgav den følgende dag. Efter hans kladdes mange overstregninger og rettelser får man det indtryk, at det har kostet ham ligeså meget besvær at skrive det, som det $\mathrm{i}$ dag volder at tyde det. Det lyder (i oversættelse):

"I anledning af den behagelige skrivelse af 27. ds. og $i$ henhold til den med Deres velærværdighed samt herrerne forstander Jacobsen og inspektør von Bülow $i$ går stedfundne mundtlige forhandling, og idet jeg tilbagesender den til gennemsyn meddelte skrivelse fra Tyrstrup herred af 9. ds., undlader jeg ikke at bemærke følgende:

Den afdøde herredsfoged Andersen kunne ifølge sin embedsstilling ligesom ved sin personlige tilknytning kende byen Christiansfeld så nøje som muligt, og hans ytringer og hans beretning, som dannede hovedkilden angånde tilstandene $\mathrm{i}$ Christiansfeld, måtte have særlig værdi for bedømmelsen af disse tilstande.

Ud fra den $i$ herredsfoged Andersens hermed tilbagefølgende skrivelse givne fremstilling af forholdene $i$ Christiansfeld og af pastor Aastrups person kunne det imidlertid kun synes ønskeligt, at denne ikke $\mathrm{i}$ fremtiden måtte beklæde sit indflydelsesrige embede for at unddrage den forhåndenværende splittelse $\mathrm{i}$ sindene $\mathrm{i}$ Christiansfeld og omegnen næringen.

Ved sagens nuværende tilstand, efter at pastor Aastrups afskedigelse eller suspension er blevet en fuldbyrdet kendsgerning, og det derfor kun drejer sig om, hvorvidt denne kendsgerning skal fastholdes, eller om den igen skal ophæves, forholder det sig for øvrigheden anderledes $\mathrm{i}$ det pågældende spørgsmål. Jeg tror nemlig, at en genindsættelse af pastor Aastrup i hans embede som prædikant i Christiansfeld ville gøre et stærkt for landets interesser uheldigt indtryk på befolkningen dér, at den ville opmuntre de danske og 


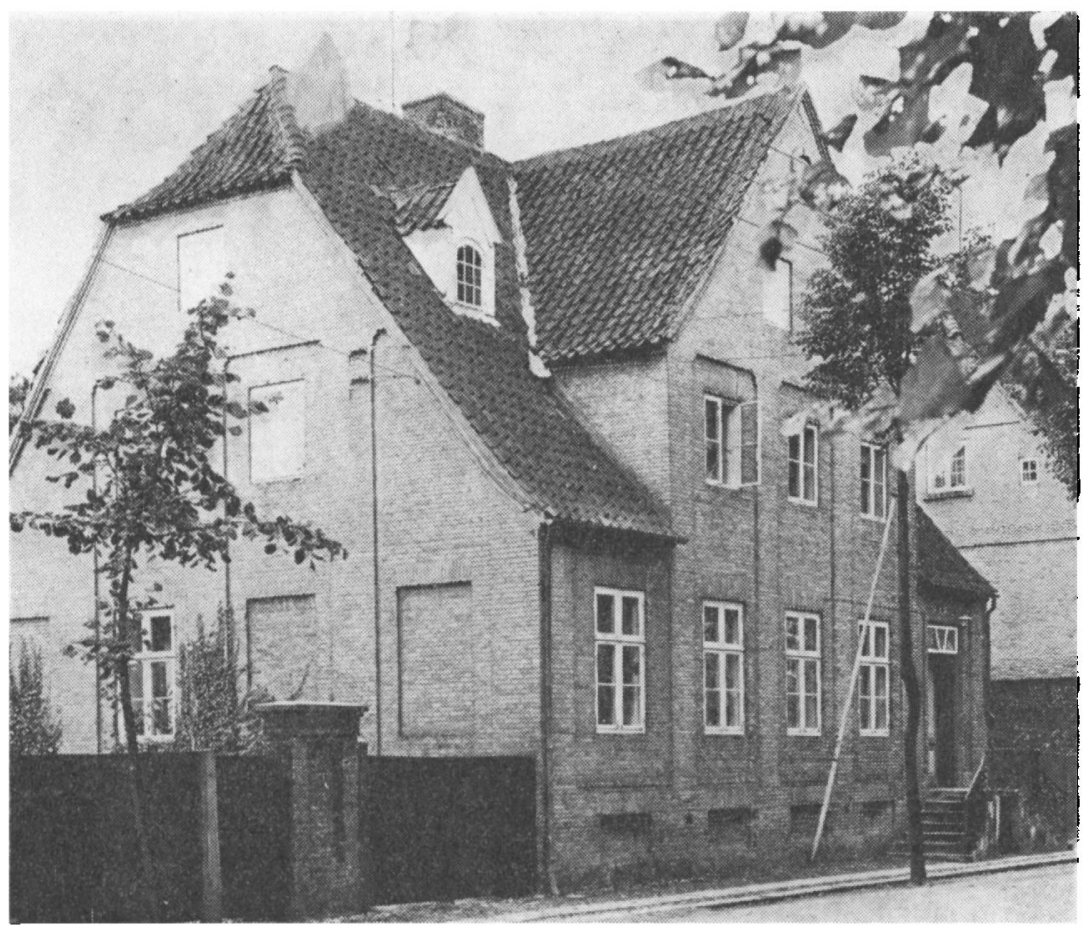

Praesteboligen, den tyske pastor Garves hjem.

deres venner og ville tage modet fra mange, som roligt har fundet sig $\mathrm{i}$ de forhold, som har deres begrundelse $\mathrm{i}$ freden af 30 . oktober d. å., og at det ganske overordentligt ville forøge tvivlen og splittelsen $\mathrm{i}$ sindene.

Men forholdene i de til Danmark grænsende egne af hertugdømmet Slesvig er af en sådan art, at der er al anledning til at skåne befolkningens fordomme og bekymringer og med den største omsorg at undgå alt, hvad der kunne give ny næring til den danske agitation, som egnen så længe har været udsat for, og jeg må derfor eftertrykkeligst fraråde en genindsættelse af pastor Aastrup.

Skulle man alligevel på kompetent sted komme til den anskuelse, at fremgangsmåden mod pastor Aastrup ikke var tilstrækkeligt motiveret, og at de mod ham foretagne skridt af en eller anden grund skulle genkaldes, så må jeg vente at få meddelelse om den definitive 


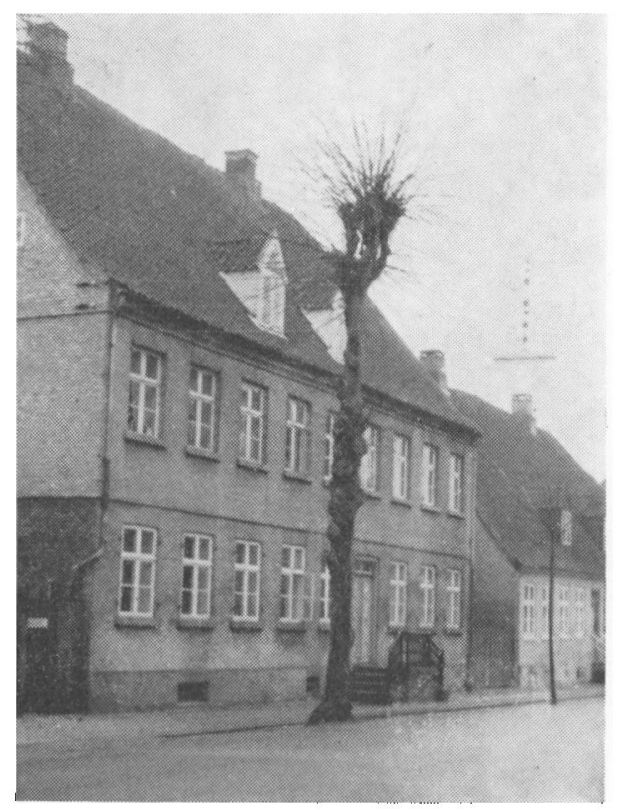

Forstanderboligen, hvor

forstander Jacobsen havde til huse.

affattelse og udførelse af sådanne beslutninger, for at jeg kan sættes i stand til evt. at kunne give den kejserlig østrigske og den kongelig prøjsiske øverste civiløvrighed for hertugdømmerne Slesvig, Holsten og Lauenborg rettidig underretning derom.

Haderslev amtstue, den 30. december 1864.«

Det er betegnende for denne skrivelse, at den overhovedet ikke nævner det centrale spørgsmål, hvorvidt herredsfoged Andersen har handlet $\mathrm{i}$ overensstemmelse med regeringen. I stedet betragter amtmanden Aastrups afsættelse (foreløbig drejer det sig jo kun om en suspension) som et fait accompli og behandler sagen udelukkende ud fra det synspunkt, der efter hans mening måtte være mest opportunt for den tyske politik, uden smålige hensyn til retfærdighed og menneskelige eller moralske overvejelser.

Når han omtaler herredsfogedens "personlige tilknytning" til Christiansfeld, må man vist gå ud fra, at den har været begrænset til hans kendskab til Garve og hans meningsfæller.

I slutningen af skrivelsen nævner amtmanden muligheden af, at 


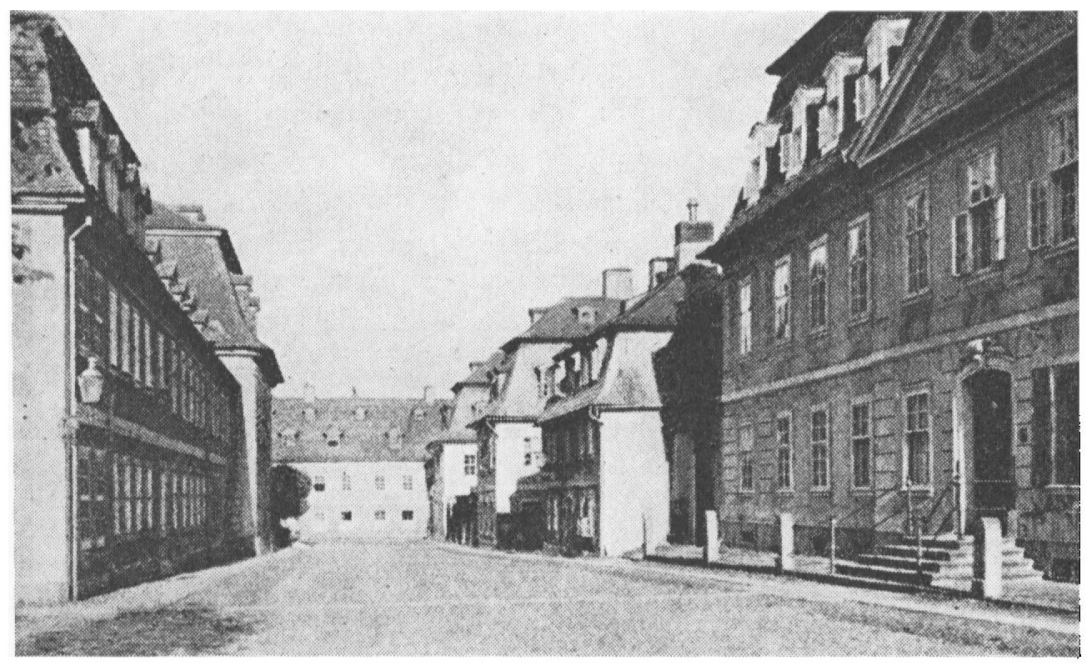

En gade i Herrnhut, der viser den for herrnhuter-kolonien typiske mansardstil.

hans argumenter ikke måtte være en »tilstrækkelig motivering “. Man må vel deraf kunne slutte, at han ikke selv har været aldeles overbevist om deres tilstrækkelighed.

Det siger sig selv, at brødremenighedens direktion i Berthelsdorf ikke har kunnet give sig tilfreds med dette svar. For dem var det jo netop afgørende at bedømme sagen ud fra spørgsmålet om retfærdighed og hensyn af moralsk og religiøs art. På direktionens vegne sendte biskop Matthiesen ${ }^{8}$ derfor et udførligt promemoria til Garve og pålagde ham først at indhente Aastrups godkendelse og derefter at overlevere det til amtmanden, som evt. skulle videresende det til "Civilkommissionen«. U. A. C.s promemoria lyder således (i oversættelse):

"Den undertegnede direktion af den Evangeliske Brødre Unitet anser sig forpligtet til $\mathrm{i}$ en åben fremstilling at give nærmere oplysning om fremgangsmåden i prædikant Aastrups sag fra brødremenigheden i Christiansfeld, resp. ved hans embedssuspension, til underretning af den høje landsregering, først af hr. amtmanden i Haderslev.

En skrivelse fra Tyrstrup herredsfoged af 9. december 1864, rettet til pastor Garve og af denne straks fremsendt til os, omtaler 
forholdene i Christiansfeld og udtaler en beklagelse af, at Christiansfeld $i$ så ringe grad var $i$ stand til at holde sig fri af landsfjendtlige indflydelser. Blandt hovedårsagerne nævnes også, "at en af den danske regering påtvungen prædikant, hvis opgave det havde været at bearbejde folket $i$ dansk ånd, og som havde forstået at forskaffe sig stor tilslutning, stadig var i funktion. Det var påfaldende, at menighedens direktion lod sådanne forhold bestå, som nu i virkeligheden betød en politisk stillingtagen, eftersom man dog nu ikke længere kunne anføre intimidering fra den danske øvrighed som undskyldning, og en personaleforandring blandt tjenestemændene $\mathrm{i}$ menigheden ikke var noget påfaldende .

Den $\mathrm{i}$ det forudgående næunte personlighed er prædikanten Aastrup, til hvem de danske prædikener i Christiansfeld er betroet, og som $\mathrm{i}$ to år har stået $\mathrm{i}$ dette embede. Skønt der fra vor side ved hans ansættelse absolut ikke har været tale om den ovennævnte hensigt »at bearbejde folket $\mathrm{i}$ dansk ånd, « men der tværtimod var pålagt ham en virksomhed uden politisk agitation, som er fremmed for brødremenighedens princip, blev vi dog gennem skrivelsen klare over, at man hos den nærmest overordnede landsøvrighed frygtede for, at predikant Aastrup ikke alene hidtil havde virket for danske interesser, men også $i$ fremtiden ville gøre det, og vi mente, at han vanskeligt ville kunne holdes i sit embede, hvis ikke hans forbliven skulle få et skær af opposition mod den nuværende landsregering. Dertil kom yderligere, at også vi under hensyn til de allerede $\mathrm{i}$ længere tid i den derværende menighed bestående to partier anså hans fjernelse for ønskelig, idet gennem nogle meddelelser derfra mistanken var opstået, om måske det ene partis overvejende tilslutning til ham og dette partis udelukkende besøg til hans prædikener skulle give anledning til politiske demonstrationer, $j a$, at der endog fra ham kunne være udgået anledning dertil. Disse to hensyn, både til det af den anførte skrivelse fremgående ønske fra regeringen og til menighedens vel, foranledigede os til beslutningen at afskedige prædikant Aastrup fra sit embede. Den nemmeste vej ville have været at forflytte ham til et andet embede og et andet sted. Dertil fandtes der $\mathrm{i}$ mangel af et vikariat for tiden ingen lejlighed. Da det imidlertid var gjort os begribeligt, at landsøvrigheden ikke ville slå sig til tåls med yderligere tøven og henholden, syntes intet andet middel end afskedigelse at stå til vor rådighed. Ved meddelelsen af denne 
beslutning blev det henstillet til prædikant Aastrup enten selv at søge sin afsked eller at imødese den, og samtidig fik han besked om indtil afgørelsen at standse sin prædikantvirksomhed for at forebygge det betænkelige ved en afskedsprædiken.

På denne meddelelse svarede han, at han $i$ den gode bevidsthed hverken før eller nu at have indladt sig på politisk agitation, ikke fra sin side kunne søge sin afsked og derfor måtte imødese den fra vor side. Samtidig forsvarede han sig så indgående og tilfredsstillende med hensyn til de kendsgerninger, der var foreholdt ham, at den ene grund til hans afskedigelse, hensynet til menigheden, ikke længere kan gxlde som motiv herfor, ja, at vi endog af gentagne skriftlige og mundtlige meddelelser er nået til den erkendelse, at en omgående afskedigelse snarere ville øge end fjerne spaltningen i menigheden. Af hans egenhæendige fremstilling har vi vundet den gode tiltro til ham, at han ikke alene $\mathrm{i}$ fremtiden ligesom hidtil vil afholde sig fra alle politiske forhold, men at han ogsa fra sin side hvis han forbliver i sit embede - efter evne vil virke for at dxmme op for partiånden samt endelig, at han ud fra sin kristelige erkendelse og overbevisning føler sig forpligtet til, nu efter at fredsslutningen er blevet en kendsgerning, overfor den nye regering at udvise al troskab og underdanighed. $\mathrm{Og}$ at vi er berettigede til en sådan tiltro, derfor borger os hans hæderlighed og hans karakters oprigtighed.

Under disse så stærkt forandrede forhold ville:

1) hensynet til prædikant Aastrup, hvem den definitive afskedigelse ville bringe $i$ det ufortjente rygte, at han $i$ sin embedsførelse virkelig havde gjort sig skyldig i noget strafværdigt,

2) hensynet til menigheden, af hvilken en stor del nu, da der virkelig ikke foreligger noget strafværdigt, med rette ville føle sig smertelig såret ved en sådan fremgangsmåde, og som allerede ved en personlig deputation har bedt os om hans genindsæettelse,

3) onsket om også fra vor side at undgå ethvert udseende af en krænkelse af fredstraktatens $\S 23$, som udelukker forfølgelsen af et politisk sindelag,

4) frygten for faren af et politisk martyrium, som prædikant Aastrup ville blive udsat for, hvis han uden embede ville forblive i Christiansfeld, give tilstrækkelig anledning til at meddele prædikant Aastrup til- 
ladelse til indtil videre at fortsxtte $i$ sit embede uden derfor at opgive tanken om hans forflyttelse for det tilfælde, at et for hans personlighed passende vikariat skulle åbne sig, og hans forflyttelse fremover skulle vise sig at være hensigtsmæssig og nyttig.

Men eftersom den nævnte skrivelse fra Tyrstrup herredsfoged har givet den første anledning til prædikant Aastrups foreløbige suspension, og efter at en deputation af Christiansfelds menighedsdirektion på vort ønske har forelagt hr. amtmanden denne sag og både mundtlig og i en skrivelse til pastor Garve af 30 . december har udtalt sine betænkeligheder mod genindsættelsen, har vi ment ikke at måtte gå videre uden først at bringe sagens gang og motiver for den hidtidige fremgangsmåde i det foranstående til hr. amtmandens kendskab og, såfremt denne skulle anse det for nødvendigt, til videre bekendtgørelse for den høje landsregering, samt at afvente velvilligt svar, idet det er os meget magtpåliggende at være $i$ overensstemmelse med den høje landsregerings vilje og således, at vi gør os værdige til den tillid, som er vist os ved den nådige anerkendelse af Christiansfelds koncession.

Berthelsdorf ved Herrnhut, den 5. januar 1865.

Direktionen for det Evangeliske Brødre Unitet ved

Christian Wilhelm Matthiesen, den evang. Brødrekirkes biskop,

Presesr.

Det må erkendes, at U. A. C. har bestræbt sig på at fremstille sagen sandfxrdigt uden egentlig at tage parti til nogen af siderne. Enkelte punkter kan man dog studse ved. Uvilkårligt spørger man, hvem der sigtes til, når der er tale om meddelelser fra Christiansfeld, der har vakt mistanke om, »at måske det ene partis udelukkende besøg til hans (Aastrups) prædikener skulle give anledning til politiske demonstrationer, ja, at der endog fra ham kunne være udgået anledning dertil«. På den anden side skal det anerkendes, at U. A. C. med stor styrke fremhæver Aastrups politiske neutralitet og hans karakters pålidelighed, der taler for, at han bør genindsættes $i$ sit embede.

Mindre tiltalende virker det på en dansk mentalitet, at U. A. C. 
ud fra disse betragtninger ikke resolut benytter sig af sin ret til at restituere Aastrup i hans embede, men i høj grad lader sig lede af politiske hensyn. Af de fire i promemoriet nævnte grunde er mindst to af politisk karakter og - hvad også skrivelsens sidste afsnit bekræfter - de viser en klar tendens til at føje magthaverne. Frem for alt burde U. A. C. have været klar over, at tiden arbejdede $\mathrm{i}$ tyskernes favør. Alle forhandlinger måtte forhale sagen. Jo længere tid, der gik til dem, des stærkere kunne tyskerne påberåbe sig det fait accompli, som amtmanden allerede havde gjort til grundlaget for $\sin$ skrivelse af 30 . december. Mere eller mindre bevidst har denne usikkerhed formodentlig været en følge af splidagtigheden i deres sind mellem deres naturlige sympati for den tyske sag og følelsen af deres religiøse forpligtelse til en overnational bedømmelse.

Amtmand Kjer har ikke været sen til at opfatte dette dilemma og til at udnytte det. Gennem pastor Garve svarede han på U.A.C.s promemoria uden at sende det til en højere instans med følgende skrivelse (i oversættelse):

\section{*Deres velarvardighed!}

Idet jeg herved tilbagesender det mig med behagelig skrivelse af 12. januar efter ordre af det Evangeliske Brødre Unitet i Berthelsdorf ved Herrnhut indsendte promemoria af 5 . januar d. à. angående prædikant $\mathrm{J}$. Aastrups suspension fra hans embede $\mathrm{i}$ Christiansfeld og samtidig sender en beretning fra herredsfogeden for Tyrstrup herred af 6. februar om denne sag, meddeler jeg Dem følgende:

Der bliver heller ikke fra vor side rejst tvivl om prædikant Aastrups personlige hæderlighed. De efterretninger, der er tilgået mig, tyder på, at Aastrup ikke alene er en begavet, men også af kristelig and besjælet og i Kristi kirkes tjeneste ivrig prædikant. Men han er i ganske utilbørlig grad danskheden hengiven. Han indrømmer selv, at han nærer stærk sympati for den danske nationalitet og er indforstået med de danskes bestræbelser for at hævde den danske nationalitet i Slesvig, og han udtaler frit og åbent, at hans politiske sindelag stadig er det samme, om end han er den regering, der har magten, underdanig og ikke foretager sig noget, som strider mod dennes institutioner. 
På et sted som Christiansfeld og i det omkringliggende grænseland, der er spaltet af skarpe partimodsætninger, og hvor befolkningen er af tvivlsom og blandet nationalitet, er en sådan politisk karakter så meget farligere, som dens befolkning hidtil har været udsat for agitation i regeringsfjendtlig forstand, og vedkommendes indflydelse kan blive skæbnesvanger for statens og menighedernes ydre og indre fred samt menighedsmedlemmernes forsoning med statens ordning af tingene, netop fordi højagtelse for personligheden og dens åndelige overlegenhed, parret med xrbødighed for den pågxldendes stilling, påvirker den uselvstændige autoritetstro hob og forbereder den til den fortræd og ufred, som den politiske agitation fører med sig.

Aastrup danner således det åndelige midtpunkt og holdepunkt for det parti, som forstyrrer Christiansfelds indre fred og modsætter sig landsregeringens intentioner. Til dette parti støtter sig så de dansksindede elementer $\mathrm{i}$ den omkringboende landbefolkning, og den skadelige indflydelse, som han på denne måde allerede har udøvet før sin suspension fra embedet, ville naturnødvendigt øges overordentligt, hvis han nu, da alles øjne efter hans suspension er rettet mod ham, blev genindsat $i$ sit ærefrygtkrævende embede og derved ville give den politiske retning, han repræsenterer, en vis sanktion.

Men også bortset herfra er det et uforsvarligt og næsten syndigt forehavende påny at fremkalde tvivl om regeringens berettigelse og varighed og dens bestræbelser $\mathrm{i}$ den hob, der så længe har været udsat for politisk agitation, og at vanskeliggøre dens forsoning med de statslige forhold, den dog må leve under.

Regeringen har $\mathrm{i}$ hvert fald pligt til så vidt muligt at afvende og forhindre en sådan fremgangsmåde, og det kan heller ikke være den ligegyldigt, hvordan et med betydelige privilegier benådet samfund inden for staten forholder sig $\mathrm{i}$ den henseende.

At overfor sådanne pligter personlige hensyn til indehaveren af et embede ligesom til enkelte menighedsmedlemmers følelser ikke ubetinget kan blive afgørende for handlemåden, kan man uden videre gå ud fra. Men en krænkelse af fredstraktatens artikel XXIII og en forfølgelse af politisk sindelag kan umuligt findes $i$, at en embedsmand på grund af sin for opnåelsen af statens mål uheldige indflydelse bliver afskediget, eller en allerede fra sin stilling suspenderet embedsmand ikke bliver genindsat, og faren for et politisk 
martyrium, som pastor Aastrup formodentlig ville blive udsat for, hvis han uden embede blev boende $\mathrm{i}$ Christiansfeld, ville over for den højere pligt ikke kunne komme $\mathrm{i}$ betragtning, selvom direktionen for Brødre Unitetet ikke skulle have et middel til rådighed for at forhindre dette martyrium.

Hvorledes direktionen af Brødre Unitetet skal forholde sig i denne sag, synes mig at være uden for al tvivl. Jeg for min part finder derfor ingen anledning til allerede nu at bringe sagen frem for den høje øverste civiløvrighed og indskrænker mig til at gentage, hvad jeg allerede har udtalt $i$ min skrivelse af 30 . december $f$. à., at jeg på det bestemteste må fraråde genindsættelsen af prædikant Aastrup.

I øvrigt henstiller jeg til Deres velærværdighed sammen med denne min erklæring at lade tilgå direktionen af Brødre Unitetet den medfølgende beretning af den nuværende herredsfoged for Tyrstrup herred, som indeholder værdifuldt materiale til bedømmelse af den foreliggende sag.

Haderslev amtstue, 16. februar 1865.«

Medens amtmandens skrivelse af 30. december 1864 måske nok kunne opfattes som en mere privat tilkendegivelse af hans personlige syn på sagen, drejer det sig her om et officielt svar på en officiel henvendelse. Det er kun rimeligt, at amtmanden har måttet føle sig bundet til sin tidligere udtalelse, og da U. A. C. med sit promemoria havde bevist som sin "anskuelse, at fremgangsmåden mod pastor Aastrup ikke var tilstrækkeligt motiveret, og at de mod ham foretagne skridt af en eller anden grund skulle genkaldes, « skulle man have fundet det mest korrekt at overlade afgørelsen til en højere instans, Civilkommissionen, der jo i øvrigt var den eneste kompetente i denne sag.

Det gjorde amtmanden altså ikke. Han har øjensynligt ment selv at kunne klare affæren og formodentligt heller ikke villet risikere at blive underkendt af den højere instans. Hans skrivelse af 30 . december 1864 må efter hans mening have gjort det tilsigtede indtryk. U. A. C.s tyske nationalisme, parret med trangen til lovlydighed mod regeringens autoritære magt, er umiskendelig. $\mathrm{Nu}$ gælder det blot om at overvinde visse religiøs-moralske hæmninger. Det regner 
han med at kunne opnå ved de prøvede midler: Sukker $\mathrm{i}$ den ene hånd $\mathrm{og}$ pisken $\mathrm{i}$ den anden.

Det kunne aldrig falde regeringen ind at bestride Aastrups hæderlighed og hans uangribelige karakter. Den øjeblikkelige situation er blot beklageligvis den, at der også må tages andre hensyn. Den brede hob, som ikke kan tænke selv, forstår ikke, hvad der tjener til dens sande vel, og lader sig derfor let vildlede af ansvarsløse demagoger. Det ville være ansvarsløst, ja, »næsten syndigt«, at levere sådanne folk propagandamateriale. Den synd vil den fromme brødremenighed da ikke begå! Skulle det forekomme U. A. C. vanskeligt at begrunde afvigelsen fra den gængse naive moral, vil det medfølgende »elaborat « af den dygtige jurist Selig give fornøden vejledning. Uden at kende dette "elaborat «s ordlyd kan man danne sig en forestilling om dets karakter efter en bemærkning i Christianfelds tyske protokol. Der tales om "juristische Schärfe, « hvad på jævnt dansk måske svarer nogenlunde til »juridiske krumspring «.

Men - og nu kommer pisken frem - modstanden mod regeringens velmenende fremgangsmåde kunne få de alvorligste følger for brødremenighedens privilegier.

Eftersom amtmancien i sin skrivelse ikke har anført nye saglige argumenter for berettigelsen af Aastrups suspension, ikke heller har overgivet den til en højere instans, har han ikke kunnet overbevise U. A. C. om rigtigheden af den trufne afgørelse. Et direkte svar til amtmanden foreligger ikke, men $i$ et brev fra Tietzen til Garve findes der en bemærkning om, at et og andet $i$ den tyske argumentation nok kunne imødegås, hvad man dog ser bort fra. Direktionen i Berthelsdorf har altså ikke villet anerkende myndighedernes fremgangsmåde, men den har indset, at den ikke kan opnå noget ad forhandlingens vej og har bøjet sig for overmagten. Formodentligt har truslen om inddragelsen af privilegierne virket stærkest. Men man vil uvilkårligt spørge, om den ville have givet så let efter, hvis den helhjertet havde ønsket en retfærdig løsning. Nu nøjedes den med at forflytte Aastrup til Gøteborg i stedet for at afskedige ham. Det var naturligvis en indrømmelse af fejltagelsen, men dog blot en halv løsning.

Det blev også ved denne lejlighed overladt til Garve at meddele amtmanden direktionens beslutning. Det gjorde han i følgende brev (i oversættelse): 


\section{$\gg$ Deres højvelbårenhed!}

Jeg skal som svar på Deres skrivelse til mig af 16 . februar sammen med en hosliggende beretning af hr. herredsfoged Selig af 6 . februar d. å., hvilke to skrivelser jeg straks havde fremsendt til Brødre Unitetets direktion, nu efter ordre fra samme ærbødigst meddele, at den herværende danske prædikant Aastrup derefter definitivt er blevet afskediget fra sit embede, og at denne afskedigelse (som jeg kan tilføje) er meddelt ham den 2. marts.

$P \mathfrak{a}$ en og anden bemærkning $\mathrm{i}$ den nævnte beretning kunne - bliver der skrevet til mig - nok svares en del, hvad der dog sømmeligt ses bort fra.

Christiansfeld, 4. marts 1865.

Med den største højagtelse,

Deres meget $x$ rbødige

Garve, præst.«

Bag dette brevs formelle facade aner man tyskerens hemmelige triumf. Garve har næppe været ked af at slippe af med en politisk modstander og en besværlig kirkelig konkurrent. Det er således betegnende, at han taler om Aastrups »afskedigelse, « skønt U. A. C. forlængst har indrømmet sin fejltagelse, og Garve ikke kan være i tvivl om, at Aastrup fremdeles skal blive $\mathrm{i}$ brodremenighedens tjeneste. For egen regning tilføjer han, at Aastrup er blevet gjort bekendt med sin "afskedigelse « - formodentlig af Garve selv. U.A.C.s bemærkning om muligheden af imødegåelser nævnes, ligesom i forbigående, som noget, der er blevet tilskrevet ham, og som han ikke behøver at stå bag, ligesom han finder det »sømmeligt, " at man undgår at uddybe det næermere.

Dermed er de officielle forhandlinger mellem brødremenighedens tyske repræsentanter og de tyske myndigheder afsluttet. Aastrups fjernelse fra hans embede i Christiansfeld er gennemtvunget uden hensyn til, at den ikke har været berettiget. Et senere efterspil udgik ikke fra brødremenigheden som sådan, men fra dansk side.

De danske medlemmer af menigheden i Christiansfeld var på ingen måde tilfredse med U.A.C.s fremgangsmåde. Da de umiddelbart efter Aastrups suspension i december 1864 sendte Christoph med deres redegørelse til Berthelsdorf (se s. 124), lå sagen ganske klar: 1) var de mod Aastrup rejste beskyldninger aldeles ubegrundede, 
2) var herredsfoged Andersen ganske uberettiget til at forlange Aastrups afskedigelse. U. A. C. måtte derfor erkende sin fejl og omgående genindsætte Aastrup $i$ hans embede. Jo hurtigere, det skete, des mindre opsigt ville afbrydelsen af hans funktion vakke.

Så meget mere har man på dansk side været skuffet over, at U. A. C. $i$ stedet for at handle snarrådigt henvendte sig til de tyske myndigheder for at udforske rækkevidden af herredsfogedens skrivelse. Formelt kan det se meget korrekt ud, det burde bare være sket, før U. A. C. satte Aastrup fra bestillingen. Som sagen nu lå, kunne de tyske myndigheder henholde sig til den kendsgerning, at det var brødremenighedens styrelse, der havde afskediget Aastrup og derved skabt et fait accompli, som ikke mere stod til at forandre.

Det er muligt, at de danske i Christiansfeld har følt sig noget brøstholdne over den mistillid, hvormed direktionen mødte deres fremstilling af sagen, men $i$ hvert tilfælde var de forargede over, at en så åbenlys uretfærdighed skulle blive ved at bestå i brødremenigheden, længere end nødvendigt, til stor skade for dens anseelse. De sendte derfor allerede $i$ januar 1865 følgende skrivelse til U. A. C. (i oversættelse):

»Til de kære brødre af U. A. C. i Berthelsdorf.

\section{Elskede brødre!}

I fortsættelse af vor skrivelse, som broder Christoph overbragte jer, og hvis indhold vi stadig vedkender os $i$ et og alt, føler vi trang til endnu engang hjerteligt at bede de kxre brødre af U. A. C. lade vor kære broder Aastrup forblive i sin velsignede embedsvirksomhed, resp. snarest genindsætte ham, eftersom hans afsættelse bevisligt savner ethvert retsligt grundlag, og den øverste civilmyndighed, hvem det jo for tiden alene tilkommer at anmode om sligt hos U. A. C., ikke, så vidt vi har bragt $i$ erfaring, har taget et skridt $i$ den retning og heller ikke med rimelighed har kunnet gøre det, da vor kære broder Aastrup ikke har givet nogen anledning dertil, hvilket jo også herværende Aeltesten Conferenz i alle punkter har måttet bekræfte. Hvis de kxre brødre af U. A. C. havde behaget at valge en repræsentant af deres kreds, for at han her på stedet personligt kunne have overbevist sig om kendsgerningerne, ville sagen efter vor formening hurtigt være kommet $i$ det rigtige spor. 
Vi beder derfor påny overveje sagen alvorligt med og for Herren og ikke af frygt eller tjenstvillighed overfor mennesker handle mod samvittigheden og en bedre overbevisning, ikke at tanke, at sagen nu må gå sin gang, efter at han er afsat, for ikke at tabe ansigt. At gøre en fejl god igen sømmer sig jo godt for en kristen, særligt da, når der foreligger omfattende beviser for de anførte bagtalelsers ugyldighed.

Helt bortset fra en stor del af herværende menighed ville mange udenbys venner af brodremenigheden tage forargelse af det, hvis udtalelsen mod broder Aastrup fremdeles skulle stå ved magt, og de måtte sige til sig selv, at uretten kan veje tungt også indenfor brødremenigheden, at også dér må der regnes med logn, misundelse og bagtalelse.

Også dette vil I, elskede brødre, forhåbentlig tage i betragtning og føre sagen til én Gud velbehagelig afslutning.

Dertil give Herren jer sin nådige bistand efter jeres og vor bøn.

Christiansfeld, den 6. januar 1865.

\section{S. Lauersen. M. Bank. P. Dabl. E. Weinert.}

Fra samme dag (6. januar 1865) foreligger et ret udførligt privat brev fra Øster til Tietzen, af hvilket der skal anføres nogle afsnit, der synes mindre forbeholdne end den mere officielle skrivelse. Således lader han skinne igennem, at herredsfoged Andersens krav om afsættelse af Aastrup anses for fremkaldt af selve den tyske præst, Garve. Det hedder (i oversættelse):

"Når vi er overbeviste om, at anklagerne, som er rejst mod broder Aastrup af underordnede embedsmænd, først er indledet herfra af lidet broderlige grunde og mod menighedens ånd, at disse anklager er aldeles usande og ubegrundede, at han tværtimod altid har været en rolig og lydig undersåt, som i stor tilbagetrukkethed kun har levet for sit embede, så kan du forestille dig, med hvilke følelser vi har modtaget efterretningen om, at brødrene af U. A. C. har lånt øre til sådanne mistænkeliggørelser. Vi må føle det, som havde en lognens og falskhedens ånd rejst hovedet, at endog tilliden til dem, der før nød den i fuldeste mål, til brødrene af U.A.C., er blevet rystet, og det næsten synes, som var Herrens sag blevet til en biting i menigheden, og som var personlige hensyn blevet til hovedsagen ... 
... Hvis vi her $\mathrm{i}$ menigheden dannede en enhed, ville vi med lethed tilbagevise alle indflydelser udefra, og ligesom vistnok brødrene af dansk nationalitet $\mathrm{i}$ de år, da vi stod under dansk styre, har brugt al deres indflydelse til menighedens vel og opretholdelsen af de gamle vedtægter, som vi elsker, således ville vi gerne have ventet noget tilsvarende af vore tyske søskende. Skulle tiderne ændre sig, ville vi da også troligt virke til vor kære herværende menigheds vel ....

Som svar på de to skrivelser af 6. januar skrev Tietzen følgende brev (i oversættelse):

\section{Kare broder Christoph!}

*Berthelsdorf, den 10. januar 1865.

Som du lovede mig ved dit kære besøg, personligt at overbringe vort svar til dine brødre på deres skrivelse, må jeg efter at have hørt om din tilbagevenden endnu engang bede dig om samme tjeneste. Der er nemlig siden da indtruffet en ny skrivelse af 6 . januar, til dels igen undertegnet af de samme underskrivere som den første, hvilken skrivelses afsendelse formodentligt også vil være dig bekendt. Deri bliver påny ansøgt om genindsættelse af broder Aastrup $i$ hans embede, og der udtales en beklagelse af, at der ikke straks er blevet foretaget en visitation fra U. A. C.s side. Hvad angår det første punkt, så ved du jo, at U. A. C. først ville instruere sig om betydningen af herredsfogedens skrivelse hertil. Dette er sket, og U. A. C. er i mellemtiden trådt i skriftlig forhandling med landsøvrigheden til fordel for broder Aastrup. Resultatet deraf må foreløbig afventes.

Med hensyn til den ikke straks foretagne visitation må jeg bemærke, at et personligt besøg ville have været formålsløst for de nævnte forhandlinger, men til granskningen af stemningen i menigheden var dine meddelelser derom tilstrækkelige, eftersom du var blevet sendt hertil i dette ojemed.

I hin skrivelse at se den mistanke udtalt, at U. A. C. af usagligt rethaveri ville fremture på den engang betrådte bane, beklager jeg fra min side så meget mere, som jeg er overbevist om noget andet.

Jeg kan ikke fortie frygten for, at hvis den nuværende bevægelse i menigheden skulle blive meget højlydt og udadtil blev bekendt, det da let kunne fremkalde en ugunstig stemning mod broder Aastrup hos regeringen. Mine onsker for menigheden har jeg af et op- 
rigtigt hjerte udtalt mundtligt over for dig; de stemte overens med dine og er endnu i dag de samme. Jeg føjer dertil kun endnu ønsket om, at det ikke må lykkes fjenden ${ }^{8}$ at så mistillid mellem os og jer, hvorved den allerede dybe skade ville blive endnu dybere. Herren forbarme sig! Idet jeg beder dig meddele denne skrivelses indhold til undertegnerne af skrivelsen af 6. januar, ligesom også til den kære broder Øster, slutter jeg i venlig erindring om dit kære besøg.

I hjertelig kærlighed som din trofast forbundne

\section{G. Tietzen.*}

Som det var at vente, forhalede U. A. C.s forhandlinger med de tyske myndigheder afgørelsen. De dansksindede i Christiansfeld blev mere og mere utålmodige, og de har vel også været klare over, at jo længere tiden trak ud, desto ringere blev deres udsigter til at få Aastrup genindsat $\mathrm{i}$ hans embede. Da der var gået over fire uger efter Tietzens brev af 10. januar, sendte de følgende skrivelse til Berthelsdorf (i oversættelse):

*Til de kare brødre

af Unitäts Aeltesten Conferenz i Berthelsdorf.

$\mathrm{Da}$ afgørelsen $\mathrm{i}$ vor kære broder J. Aastrups sag trækker så meget i langdrag, kan vi ikke undlade endnu en gang at rette nogle linjer til de kære brødre af U. A. C. Ved broder S. Christoph er en skrivelse fra den kære broder Tietzen blevet os meddelt, hvori vi bliver opfordret til at have tillid til brødrene af U. A. C., og vi følger med glæde denne opfordring, dog må vi indrømme, at den lange tøven ikke kan styrke denne tillid. Ønsket om vor herværende menigheds, vore udenbys søskendes og talrige $\mathrm{i}$ omegnen boende venners vel indgiver os håbet, at det virkelig er de kære brødre af U. A. C.s vilje, at broder J. Aastrup også i fremtiden må fortsætte sin hidtidige så rigt velsignede virksomhed i Herrens vingård. Vi kan bevidne, at ikke politikken, men den rene og indtrængende prædiken af evangeliet og trangen til opbyggelse har hidført de mange tilhørere, som nu indtrængende ønsker hans genindsættelse, og at sxrdeles mange sjale vil tvivle om menigheden og dennes direktion, hvis en så åbenbar uret skulle opretholdes. Thi efter en tydelig erklæring fra vort lands øverste myndighed ligger genindsættelsen af vor kære broder Aastrup udelukkende i hænderne på U. A. C. Skønt 
vi er fuldkomment overbeviste om den gode indsigt og visdom hos brødrene i U. A. C., foranlediges vi dog af den lange tøven, hvis årsag vi ikke kan forstå, til at foreslå de kære brødre at henvende sig direkte til den øverste civilmyndighed for hertugdømmet Slesvig, navnligt til hans excellence, hr. president, friherre von Zedlitz, eller også at give vor kære broder J. Aastrup fuldmagt til at foretage et sådant skridt. I begge tilfælde er vi overbeviste om, at vor broder Aastrup snart vil blive restitueret $i$ sit embede, så meget desto mere, som han i sin egenskab af rolig og lydig undersåt kan gøre regning på regeringens agtelse og velvilje. Skulle de kære brødre af U. A. C. imidlertid ikke vare villige til at gå ind på disse forslag, ville vi være nødsaget til selv at foretage et skridt ved landets øverste regering, som andre menigheder også allerede har gjort for at beholde deres præster, og at klage over, at amtmand Kjer i Haderslev på trods af vore koncessioners stadfæstelse ikke vil efterkomme U. A. C.s ønske, men lægger hindringer $\mathrm{i}$ vejen for broder Aastrups genindsættelse. Vi har det håb også ad denne vej at nå vort mål.

Det har berørt os meget smerteligt, at et embedsbesøg fra U.A.C. har fundet sted i Stettin, men at det ikke har været muligt at besøge os. Thi foruden vor broder Aastrups sag er der adskilligt andet, navnligt i Chorhusene, som nok kunne gøre tilstedeværelsen af en broder fra U. A. C. nødvendig, og herværende menigheds trængsler ville blive betydelig lettere, hvis vi følte virkelig og virksom deltagelse.

Skulle det end synes, som om Christiansfeld for tiden helt var unddraget den danske regerings område, så vil vi dog gøre opmærksom på, at det måtte forekomme denne mærkeligt, at brødremenigheden søger at udbrede evangeliet i Grønland og Vestindien, medens den her $\mathrm{i}$ landet søger at lukke de åbne døre og tømme den fyldte kirke.

Endelig beder vi at optage også denne skrivelse i kærlighed og være forvissede om, at kun ønsket om vor herværende menigheds vel har været vor rettesnor. Vi forbliver

Eders i Herren trofast forbundne brødre.«

Dette brev er antageligt skrevet omkring midten af februar. Det omtales $i$ et brev af Tietzen til Garve af 28. februar, hvori det hedder: 


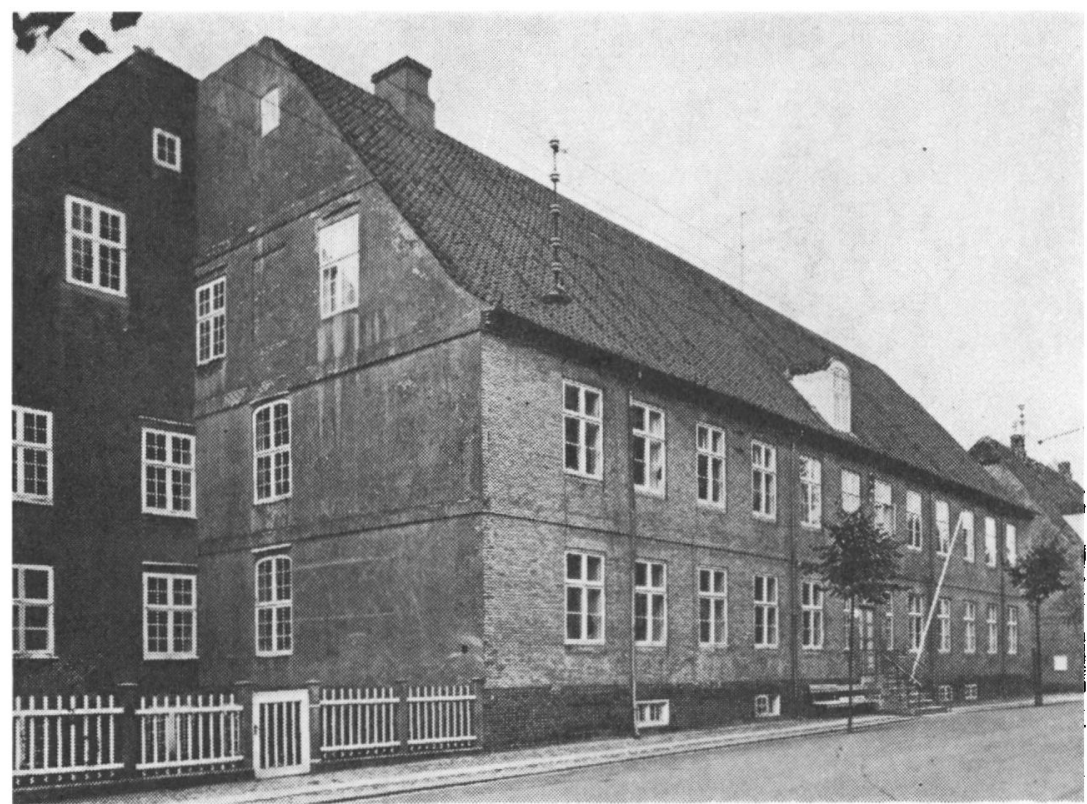

Sostrehuset i Christiunsfeld, et af „chorhusene“.

I det tilsvarende brodrehus fandtes olstuen.

"For nylig modtog vi atter en skrivelse fra Christiansfeld, undertegnet af brødrene Lauersen, Øster, Joh. Bau og Bank, i broder Aastrups sag med forslag, som ikke kan gennemføres... «

De forslag, som Tietzen erklærer for uigennemførlige, må formentlig hentyde til det danske ønske om, at U. A. C. henvender sig direkte til friherre von Zedlitz. Slet så umuligt kan det dog nxppe have været. Iflg. et protokollat $\mathrm{i}$ Christiansfeld havde Aastrup nemlig den 9. januar haft en samtale med denne Zedlitz, og denne synes at have anerkendt berettigelsen af de danske anker, som også var fremkommet i U. A. C.s promemoria. Eftersom amtmand Kjer simpelthen havde forbigået det centrale problem med tavshed, ville en henvendelse til den højere, for disse spørgsmål kompetente, instans have været ret naturlig, så meget mere, som Tietzen allerede den 10. januar $i$ et brev til Garve havde ytret (i oversættelse):

»Det ville være onskeligt, at amtmanden ville lade vor promemoria gå videre til Civilkommissionen, for at, lige meget hvordan svaret måtte falde ud, ingen åbne spørgsmål blev tilbage...\& 
Underskriverne af henvendelsen til U. A. C. har efter Aastrups samtale med Zedlitz haft et "håb om også ad denne vej at nå vort mål, « hvis de skulle se sig tvungne til at betræde den.

Man har svært ved at betragte U. A. C.s handlemåde som andet end et forsøg på at skaffe sig et alibi i en kedelig sag, som den måske mod sin vilje, men ikke uden egen skyld, var blevet impliceret i; det negative udfald af sagen næppe har forvoldt de ledende mænd nogen større sorg.

Forhandlingernes resultat blev som tidligere omtalt (s. 138), at U. A. C. gav afkald på at gennemføre sagen til bunds og faldt til føje efter amtmandens ønske, idet man påberåbte sig Paulus-ordet fra Rom. 13 om at underordne sig de foresatte myndigheder.

Bitterheden i Christiansfelds danske kredse finder sit tydelige udtryk $\mathrm{i}$ et brev, som de efter dets indhold må have sendt til Berthelsdorf efter 2. marts 1865. Det lyder (i oversættelse):

»Til medlemmerne af U. A. C. i Berthelsdorf.

\section{Elskede brødre!}

Eftersom vi må antage, at vor kære broder Aastrups sag $i$ denne omgang er afgjort, kan vi ikke undlade endnu en gang afsluttende at udtrykke vore tanker overfor jer.

$\mathrm{Vi}$ håber, at grundene for hele fremgangsmåden ved den officielle meddelelse til herværende menighed vil blive fremlagt, thi for os, som fra nært hold har kunnet iagttage vor kære broder Aastrup, er der ikke det allermindste bekendt, som hverken for en verdslig eller en gejstlig ret kunne foranledige eller retfærdiggøre hans afsættelse. Tværtimod savner vi smerteligt den opbyggelse, der blev os og mange venner og naboer til del $\mathrm{i}$ hans prædikener.

$\mathrm{Da}$ synoden af året 1857 har påbudt regelmæssige visitationer $\mathrm{i}$ menighederne og med dette formål for oje har oget antallet af U. A. C.s medlemmer, er vi meget forundret over, at ingen broder på vor gentagne bøn har villet komme hertil, skønt vor menighed her hårdt trængte til sådan et besøg. Men så længe som U. A. C. lader sig bruge som værktøj for et politisk parti, og vi må føle, at $\mathrm{i}$ dens kreds den politiske mening har indflydelse på hjertet og sindelaget overfor medbrødre, er det ikke at tænke på, at sindene her vil falde til ro. Hvis de kære brødre af U. A. C. i øvrigt tror, at 


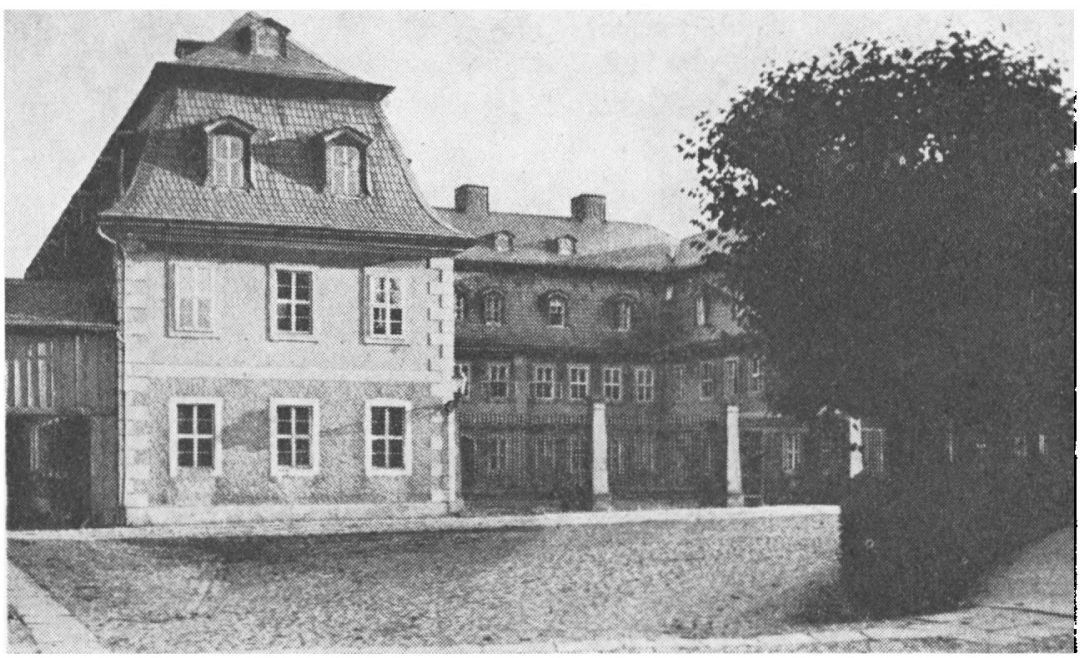

Et „chorhus" i Herrnhut.

man måtte frygte for forstyrrelser af den ydre ro og orden, tager de meget fejl, og også $\mathrm{i}$ den henseende ville et besøg her fuldkomment kunne berolige dem. $\mathrm{Vi}$ vil med glxde underordne os den $ø v-$ righed, der har magt over os, men at vi pludseligt skulle hade, hvad vi i mange år har elsket og værdsat, det som vi af hjertet har bedt for til Herren, at vi skulle holde op med at bede for den nation, som vi tilhører, og hvis sprog vi taler, er dog nok ikke meningen med Guds ord.

Vi er helt enige med jer heri, at mange øjne i denne tid fra omegnen hviler på Christiansfeld og iagttager, hvordan en menighed $\mathrm{i}$ en sådan tid står sin prøve. Men vi er også overbeviste om, at aldrig nogen begivenhed har sat vor menighed og dens direktion $i$ et dårligere lys overfor vore omgivelser end netop broder Aastrups afsættelse, der kun kan forklares som en følge af nationalhad. Vi skjuler ikke for os selv faren ved vor menigheds nuværende tilstand, vi føler nok, at vi er på en afvej, men vi beder om dog ikke altid at blive ensidigt bedømt, at man ikke vil søge al skyld på den ene side, men at det måtte vises os på en tydelig måde, at U. A.C., skønt den består af tyske mænd, dog ikke ser sin hovedopgave $i$ at udbrede tysk nationalitet og sprog på jorden og værne om dem, om 
det så måtte gå med Guds rige, som bedst det kunne, men at Frelserens sag må være hovedsagen i menigheden, at vi alle må ydmyge os for ham som vor eneste konge og vort evige hoved. Hertil ville vi gerne påny slutte os sammen med jer, og vi ville glæde os over at få en forsikring om, at ikke heller fra jer side forskelligheder $i$ synet på ting $\mathrm{i}$ det ydre liv kan sønderrive det bånd, der binder hjerterne sammen.\&

\section{Efterdonninger af Aastrup-sagen.}

Dette brev danner afslutningen af korrespondancen mellem de danske menighedsmedlemmer i Christiansfeld og direktionen i Berthelsdorf. Anstrengelserne for ved hjxlp af U. A. C. at beholde Aastrup i Christiansfeld havde været resultatløse. Det eneste, man havde opnået, var en vis xresoprejsning for Aastrup, der, i stedet for at blive afsat fra brødremenighedens tjeneste, blev forflyttet til Gøteborg. Den 13. maj 1865 rejste han til sit nye virkefelt.

Vigtigere er det dog måske, at dette udfald $i$ en dybere forstand blev et vendepunkt $i$ de danskes indstilling.

Oprindeligt havde det for dem været aldeles selvfølgeligt, at der i brødremenigheden kun fandtes én opgave, at fremme Guds rige, og at alle andre hensyn måtte vige for dette ene. Lige så selvfølgeligt måtte det være, at brødrene $\mathrm{i}$ denne kirkes ledelse ubetinget måtte handle efter dette princip. Det var grundlaget for deres autoritet.

Da nu Aastrup midt $\mathrm{i}$ »sin velsignelsesrige virksomhed « for Guds riges fremme modtog meddelelsen om sin afsættelse, resp. suspension, kunne de ingen anden forklaring finde end den, at U. A. C. gennem Garve, hvis udpreget tyske sympatier de havde mange vidnesbyrd om, var blevet forkert underrettet om den sande sammenhæeng.

Dette var situationen, da de danske i Christiansfeld sendte Christoph med deres redegørelse til Berthelsdorf. De havde da den tillid til U.A.C., at den omgående ville erkende sin fejltagelse og restituere Aastrup i hans embede.

Det blev deres første skuffelse, at U. A. C., i stedet for en resolut handling efter brodremenighedens princip, valgte forhandlingens mistænkelige vej, der foranledigede den livlige korrespondance med Tietzen. Eftersom denne gang på gang afviste deres forslag, opdagede de med voksende klarhed, at mandene i direktionen ikke 
svarede til de forestillinger, de havde gjort sig om dem. De lod sig $i$ høj grad påvirke af nationale sympatier og af menneskefrygt. Dermed var grundlaget for deres autoritet bristet og veg omsider for åben mistillid.

Denne mistillid til de ledende mænd var dog ingenlunde rettet mod selve brødremenigheden. Den følte de sig stadig knyttet til med stærke bånd. De anerkendte deres egen fare for at blive lunkne over for det centralt religiøse, i samme grad som de nationale lidenskaber fik magt over dem. Det kunne vanskeligt undgås i grænseområdet, og de drøftede - allerede før Aastrups afrejse til Gøteborg - planer om at udvandre nordpå for at grundlægge en ny herrnhuter-koloni i Jylland med Aastrup som præst. Foreløbig havde disse planer ikke taget fast form, men de er formodentlig kommet mere $\mathrm{i}$ forgrunden, da den endelige afgørelse i Aastrupsagen gik de danske imod.

Så utilfredsstillende denne udgang dengang har været for dem, har vi dog netop den at takke for et interessant indblik $i$ denne periodes forhold i Christiansfeld. Efter Aastrups bortrejse til Gøteborg skrev Øster nemlig en række breve til ham for at holde ham underrettet om de forskellige faser $i$ den nationale kamp. Udkastene til disse breve, suppleret med enkelte andre dokumenter, danner hovedindholdet af de folgende blade. Som ven til ven udtaler Øster sig uforbeholdent om begivenheder og personer, som de begge er fortrolige med. Det kan på den ene side hist og her nødvendiggøre en kommenterende bemærkning, men vil på den anden side give et ret levende billede af tilstandene.

Det første af disse breve er dateret den 17. juni 1865. Det omtaler en rejse, som Bank, en af det danske partis forende mænd i Christiansfeld, har foretaget til Tyskland, åbenbart for endnu en gang at klage over Aastrups afskedigelse. Ved denne lejlighed har han for første gang over for U. A. C. omtalt tanken om at grundlægge en herrnhuter-koloni i Jylland. I Østers brev hedder det:

". . Nogle dage efter din afrejse kom broder Bank ${ }^{10}$ hjem fra sin rejse til Tyskland, han har med frimodighed sagt brødrene i U. A. C. sandheden. Joseph Mathiesen var hans tolk, men tilsidst ville Tietzen ingen tolk have, da han vel syntes, de drøje sandheder ikke passede for tredje mands øre. C. Simonsen havde også været med og 


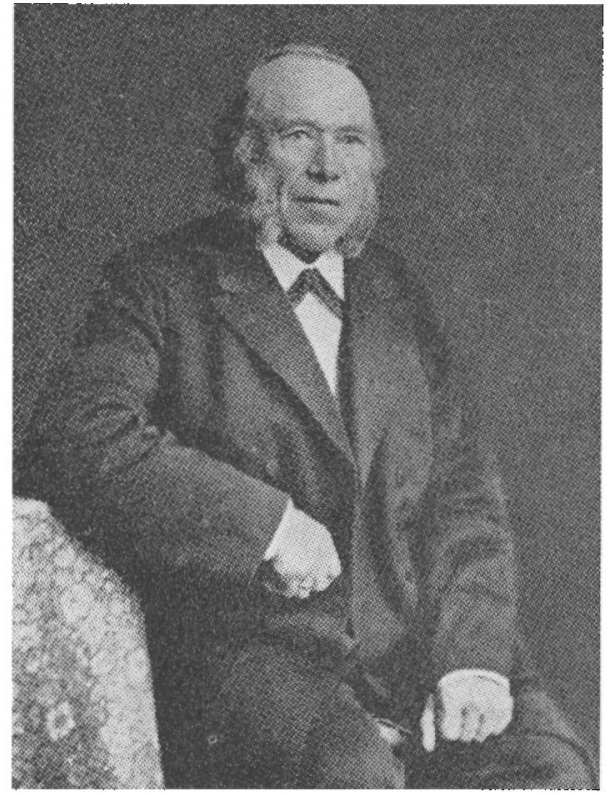

Rebslagermester Oster, forfatteren af brevene til Aastrup og de fleste andre dokumenter fra dansk side.

samstemmede fuldkommen med vores anskuelse, ja udtrykte den næsten endnu skarpere. Bank havde lagt dem det hele ansvar på hjertet, som både her og hisset ville hvile på en så uretfærdig frem" gangsmåde. Tillige havde Bank forespurgt, om de ikke syntes om at grundlægge en menighed i Jylland. Svaret var naturligvis undvigende, dog ikke afslående. De gav Bank opdrag om først at få at vide, hvor mange søskende der ønskede en sådan plan udført, herpå have vi ikke syntes endnu allerede at kunne indgå, da jo ingen gerne vil binde sig til at rejse, for man endnu ved, om der bliver noget af en sådan menigheds anlæggelse. Bank er $\mathrm{i}$ denne tid rejst til Jylland og vil dér forhøre blandt de opvakte og med menigheden forbundne søskende, hvor stort ønsket blandt dem efter en menighed måtte være. Imidlertid blev gården Volstrup udbudt til salg i "Aarhus Avis «, hvilket var os meget mærkeligt. Bank vil foreløbig også forhøre, hvorledes handelen måske kunne ordnes, conditionerne havde vi alt tidligere modtaget fra København, dog er naturligvis alt kun ganske løst. Et par brødre ville have gjort rejsen derned, men da de talte med forstander Jacobsen, tilrådede denne at vente, 
indtil Bank kom tilbage. Hvad synes nu du om alt dette? Hvis du kunne få lejlighed, da beder jeg dig at skrive mig din mening. Jeg tror nu $\mathrm{i}$ det hele ikke, at U. A. C. vil gøre noget, når det kommer til stykket, men det kunne også være, at vi måske selv kunne klare sagen, imidlertid er enkelte bange for, at Bank ville misbruge den indflydelse, hans penge muligvis kunne forskaffe ham. Når det kommer til stykket, er der også så mange bånd, der knytter én til hjemmet, at man har svært ved at rive sig løs.

Hovedøjemedet med disse linjer er imidlertid et andet. I den sidste tid har der været en fyrst af Hohenlohe ${ }^{11}$ i Haderslev for at høre befolkningens klager over embedsmændene. Sxrdeles mange folk fra Haderslev og hele omegnen var mødt, og det lod til, at han interesserede sig meget for det, han hørte, og lovede, at alt skulle blive undersøgt. Man venter derfor en kommission til Haderslev. $\mathrm{Nu}$ ville jeg spørge, om du synes om, at vi forebringer din sag for denne kommission, da den netop er et eksempel på embedsmændenes overgreb. Hvis du synes det, ville jeg spørge dig, om der i det sidste brev fra U.A.C., hvori din afsættelse endelig blev afgjort, var anført som grund for denne ovrighedens onske om din fjernelse, om du synes, at din samtale med amtmanden kunne benyttes, og da hvor meget, da der måske kunne forlanges en retslig bevidnelse af dit udsagn. Du har jo vist ingen afskrift af Andersens brev til U. A. C., for dette var det allerbedste, men du kunne måske skaffe afskrift af de vigtigste steder af det forste brev fra U. A.C., som du modtog den 19. december, naturligvis kun hvad øvrighedens optræden angår. Skulle jeg imidlertid forurolige dig med dette, beder jeg dig ikke at tage nogen notits af mine spørgsmål, for om du også ikke ville tage nogen del i klagen, kunne vi jo dog forebringe, hvad vi vidste, så kunne de gøre dermed, hvad de ville, kendsgerningerne taler selv stærkt nok ....

Skønt planerne om at købe Volstrupgård for at anlxgge en ny herrnhute-koloni og Hohenlohes besøg i Haderslev ikke umiddelbart synes at have noget med hinanden at gøre, var der alligevel en vis sammenhæng mellem dem.

Straks efter Wiener-freden var Østrig og Prøjsen blevet enige om, at de i fællesskab skulle administrere hertugdømmerne. Det førte imidlertid til svære gnidninger mellem disse to rivaliserende stormagter. $\mathrm{Da}$ nu ostrigerne favoriserede augustenborgerne, styrede 
prøjserne en hårdere kurs mod disse. Det kunne endog maskeres som retfærdighed, idet man drog de augustenborgske embedsmænd til ansvar for de overgreb, de havde gjort sig skyldige $i$, og det vil sige, at de fleste underordnede embedsmænd, som var augustenborgere, blev ramt. Hohenlohe havde fået det hverv at undersøge alle uregelmæssigheder, og for de dansksindede kunne det nok tage sig ud, som om deres værste trængsler nu var overstået.

Selv om sønderjyderne ret hurtigt fik færten af, at de ikke skulle vente sig ret meget af det tilsyneladende mildere klima, var presset dog på den tid mindre trykkende, og man var da i Christiansfeld også mindre tilbøjelig til den udvandring til Jylland, som altid ville være et vovestykke, og som ingen onskede. Dertil kom, at man netop nu måtte anse det for sin første pligt at blive på sin plads for at føre sine berettigede klager frem.

Det er netop sådan en klage, Østers næste brev til Aastrup drejer sig om. Brevet er dateret den 14. juli, altså selv samme dag som den skrivelse, der her (s. 122) er anført som resumé. Da denne henvendelse er undertegnet af Øster og Lauersen, kan der ikke være tvivl om, at den i brevet omhandlede klage er identisk med resuméet, der netop bl. a. anfører dele af Aastrups samtale med amtmanden. Dem har Aastrup ojensynligt givet sit samtykke til at benytte $\mathrm{i}$ et brev, der her takkes for. I Østers brev hedder det:

»Et par dage efter, at jeg havde afsendt brevet, fortrød jeg næxsten, at jeg havde begyndt at tale med dig om Hohenlohes sendelse, men derpå kom igen rygtet om en kommission, som var kommet til Haderslev, og så ønskede jeg jo at bringe sagen frem; en aften kom Sabroe $^{12}$ herigennem, og jeg ventede da på ham i gæstgivergården, men da han kom, mente han, at den kommission kun søgte at forhindre klagernes fremgang, imidlertid må dette nu have forandret sig, thi i mandags fik Ebbesen ${ }^{10}$ opdrag så snart som muligt at få det i stand, som vi ønskede indgivet. I dag kom nu Sabroe her til mig og modtog af mig en kortfattet beskrivelse af den hele fremgangsmåde imod dig med nogle sxtninger af amtmandens samtale med dig. Da han havde hørt det, mente han, det var aldeles nødvendigt, at det blev indsendt. Zedliz skulle privat have skrevet til Friis i Ejsbøl $^{13}$ og bedt ham at tilvejebringe alt, hvad der var muligt, så det lader til, at prøjserne interesserer dem for at få noget imod de augustenborgske embedsmænd. 
At der kan opnås et virkeligt resultat enten for dig eller os, det venter jeg naturligvis slet ikke, men jeg synes, at når vi ikke benyttede denne lejlighed til at underrette øvrigheden om, hvorledes de underordnede embedsmænd have gjort indgreb $\mathrm{i}$ vore forhold, ville vi derved begå en forsømmelse, og $i$ en sådan tid er det enhvers pligt at bidrage sit til, at den danske nationalitet kan vise, $i$ hvor høj en grad den er blevet forurettet, om man også derved skulle få lidt besvær og ubehagelighed. Jeg synes også fra menighedens standpunkt ikke at forse mig derved, da vi dog kun handler i øvrighedens opdrag og interesse, og det må blive klart for enhver, hvor sandt det var, da vi gjorde U. A.C. opmærksom på landets virkelige regering og de underordnede augustenborgske embedsmænd. Hvad skrivelsen selv angår, så fandt jeg mig ikke rigtig tilfreds med den, den var for kort, men de andre mente, at det kunne gå an, og Sabroe syntes, det var aldeles nødvendigt, at den blev afsendt. Søren Lauersen underskrev den med mig. Jeg havde anført en sætning deri, at amtmanden $i$ sit sidste svar havde truet med indkvartering, hvis ikke din afskedigelse gennemførtes, men måtte udelade den, da Lauersen ikke ville have noget dermed at gøre, og jeg heller ikke selv kunne påstå det. Gormsen ${ }^{10}$ har nemlig meddelt mig det som bestemt, men han mente det var fra dig, han havde hørt det. Kan du med sikkerhed sige, at der har stået en sådan trussel $\mathrm{i}$ et brev og da i hvilket? Vil de have videre oplysninger, kan de jo få dem. Gormsen er $\mathrm{i}$ denne tid rejst til Jylland, og så kunne jeg ikke rådføre mig med ham om dette krav.

$\mathrm{Nu}$ håber jeg, du vil være tilfreds med disse skridt ...

Hvad menigheden i Jylland angår, så må jeg tilstå, at sagen er gået $\mathrm{i}$ stå, måske ikke uden lidt skyld fra min side, da jeg ikke har haft mod til at drive på sagen, fordi jeg vel næppe selv $\mathrm{i}$ denne tid kunne beslutte mig til at tage del. I Jylland findes der en del, ${ }^{14}$ som ønsker at slutte sig til en sådan menighed, men de ville se en begyndelse, førend de vil gøre noget, og så håber vi, at det skal blive dansk igen, og at vi kunne blive....

At de danskes henvendelse til Civilkommissionen blev indgivet på dette tidspunkt, skyldtes naturligvis, at det måtte synes politisk gunstigt. Selv om man ikke ventede, at det ville få nogen praktisk betydning, håbede man $i$ det mindste at få en af augustenborgernes 
vilkårligheder trukket frem i lyset. I øvrigt gik man nu selv den vej, som man havde foreslået direktionen i Berthelsdorf, og som af Tietzen var blevet erklæret for ufarbar. Mange muligheder var i mellemtiden forsømt. Var initiativet dengang blevet taget af en tysk korporation, ville det formodentligt have mødt større velvilje, end når det nu kom fra dansk side. Tiden havde ubetinget arbejdet $\mathrm{i}$ tyskernes favør. Helt bortset fra, at det altid ville være en mislig sag for en tysk myndighed at desavouere et for ivrigt underordnet organ, var der nu gået lang tid, siden Zedlitz havde udtalt, at amtmanden ikke kunne forhindre Aastrups genindsættelse. Det kunne snart være glemt. Desuden havde direktionen nu virkelig anbragt Aastrup på et andet sted, og dermed kunne man med en vis formel ret lægge hele ansvaret på U.A.C., uden at man behøvede at gå $i$ enkeltheder, der lå et halvt år tilbage i tiden.

Trods alt blev klagen $\mathrm{i}$ det mindste $\mathrm{i}$ formen behandlet korrekt. Civilkommissionen overgav den til landsregeringen, og denne lod den gå videre til amtmandens erklæring med folgende skrivelse (i oversættelse):

"Amtshuset $\mathrm{i}$ Haderslev anmodes om at forsyne landsregeringen med en beretning og en betænkning om den $i$ bilag medfølgende henvendelse af rebslagermester Øster og købmand Lauersen i Christiansfeld angående afskedigelsen af pastor Aastrup i Christiansfeld og samtidig returnere bilaget.

Slot Gottorp, den 8. august 1865.

\section{Den slesvig-holstenske landsregering."}

I sin beretning og betænkning fralægger amtmanden sig ethvert ansvar for Aastrups afskedigelse. Han skriver (i oversættelse):

"Af den medfølgende skrivelse fra pastor Garve i Christiansfeld vil den høje landsregering for Slesvig-Holsten se, at den in rubro tænkte sag er fremkommet ved en skrivelse fra den nu afdøde justitsråd og herredsfoged Andersen for Tyrstrup herred til pastor Garve i Christiansfeld, og at den danske prædikant Aastrup derpå den 19. december modtog en skrivelse fra Unitäts Aeltesten Conferenz, iflg. hvilken han skulle søge afsked fra sit embede eller imødese sin afskedigelse, men at han, for at undgå demonstrationer, ikke mere skulle optræde offentligt. 
Først efter at dette var sket, er sagen blevet fremført for amtstuen, og jeg har efter ønske fra Unitäts Aeltesten Conferenz, overbragt til mig ved forstanderskabet i Christiansfeld, mundtlig forhandlet med Christiansfelds forstanderskab og derefter skriftligt meddelt mit syn på sagen.

En direkte indflydelse på den den 2. marts foretagne afsættelse af pastor Aastrup har amtstuen ikke haft og efter omstændighederne heller ikke kunnet have, og pastor Aastrups afskedigelse er en fri handling af U. A. C. i Berthelsdorf.

Det vil ikke være nødvendigt at komme nærmere ind på klageskriftets forskellige udsagn om mine påståede ytringer $\mathrm{i}$ sagen. Jeg tillader mig blot at bemærke, at der $\mathrm{i}$ den findes et referat af en samtale mellem pastor Aastrup og mig, hvilket referat indeholder både ligefremme usandheder og slemme fordrejelser.

Jeg beder om tilbagelevering af de til herværende arkiv hørende akter efter deres afbenyttelse «.

En kritisk gennemgang af denne skrivelse må være formålsløs. Den er affattet med den juridiske behændighed, der undgår oplagte usandheder og samtidig giver et helhedsbillede, der tilfredsstiller skriverens og evt. også modtagerens ønsker. En nøjere prøvelse af amtmandens skriftlige meddelelse om "hans syn på sagen « kunne måske have gjort det omtvisteligt, hvor vidt amtstuen ikke har haft en "direkte indflydelse på den foretagne afsættelse " og hvor vidt "Aastrups afskedigelse er en fri handling af U. A. C.«.

Petitesser af den art går man let hen over, ligesom man ikke finder anledning til at berøre spørgsmålet om amtmandens berettigelse til at besvare U. A. C.s promemoria uden at forelxgge det for Civilkommissionen. Sagens kerne er, at afskedigelsen er brødremenighedens indre anliggende, der ikke vedkommer landsregeringen, som derfor ikke skal ulejliges med kværulerende klager.

Eftersom amtmanden giver afkald på en nærmere specifikation af de »ligefremme usandheder og slemme fordrejelser « af hans udtalelser overfor Aastrup, afskærer han muligheden for en undersøgelse af dette forhold. Man undrer sig bare over, at han ikke har fundet anledning til at gøre så grove beskyldninger til genstand for en injuriesag. Dem var tyskerne ellers flinke til at rejse $i$ den politiske kamp.

Landsregeringen har anerkendt amtmandens redegørelse som fuldt 
ud fyldestgørende og på dette grundlag besvaret de to christiansfelderes henvendelse med følgende "Eröffnung" (i oversættelse):

"I anledning af den til den øverste civiløvrighed indgivne og af denne til landsregeringen indsendte skrivelse fra rebslagermester Øster og købmand Lauersen i Christiansfeld angående afskedigelsen af den daværende præst, Aastrup, skal man herved meddele Dem, at landsregeringen, da de $\mathrm{i}$ skrivelsen mod virksomheden af amtmanden for Haderslev amt $i$ denne anledning fremforte klager efter indseende med akterne har vist sig at være ubegrundede, og pastor Aastrups afskedigelse er foretaget af direktionen for den Evangeliske Brødreunitet $\mathrm{i}$ Berthelsdorf, ikke finder anledning til at foretage sig videre $i$ sagen.

Slot Gottorp, den 31. august 1865.

Den slesvig-holstenske landsregering.

Christensen. / Rathjen.

Meddelelse til rebslagermester Øster og købmand Lauersen, Christiansfeld.«

\section{Visitation $i$ Christiansfeld.}

Af praktisk betydning kunne denne "Eröffnung « ikke mere blive, efter at Aastrup havde tiltrådt sit nye embede i Gøteborg. Det var der heller ingen af de danske i Christiansfeld, der havde ventet. Derimod var det ikke uden værdi, at landsregeringen principielt havde indtaget den stilling, at brødremenighedens styrelse $\mathrm{i}$ Berthelsdorf bar ansvaret for Aastrups afskedigelse. Dermed havde den indirekte givet danskerne medhold $\mathrm{i}$, at hverken herredsfogeden $\mathrm{cl}-$ ler amtmand Kjer kunne have forhindret dem $\mathrm{i}$ at genindsætte Aastrup i hans embede. Det er ikke utænkeligt, at man omsider i styrelsen i Berthelsdorf er kommet til den erkendelse, at det var tilrådeligt at tage mere hensyn til de danske røster. Havde man gjort det $i$ tide, ville man have undgået at blive manøvreret ind $i$ den særdeles ubehagelige stilling at stå med hele ansvaret. Hvis de havde gjort regning med, at den danske modstand hurtigt ville forsvinde, har de taget grundigt fejl. Snarere end mindre er den politiske uro blevet større, og tilliden er, som det sidste brev fra Christiansfeld til U. A. C. tydeligt har vist, gået til. Man kan ikke se bort fra den mulighed, at U. A.C. under disse forhold har folt sig tilskyndet til 
en større forhandlingsvenlighed. De danske havde dengang, allerede ved juletid, bedt om en visitation. Den havde Tietzen på en temmelig overlegen måde afvist. $\mathrm{Nu}$ finder man en anledning til at komme tilbage til spørgsmålet. Den 23. september 1865 hedder det $i$ et brev fra Tietzen til Garve (i oversattelse):

»U. A. C. har til dels i bevidstheden om det den af synoden givne pålæg, til dels med hensyn til de i Christiansfeld rådende forhold allerede flere gange drøftet tanken om et officielt beseg i denne menighed, men har hidtil ment hellere at skulle afvente en fast ordning af byens fremtidige politiske forhold. Ved den nyeste konvention synes dette imidlertid snarere at være udskudt yderligere, og det må derfor anses for uheldigt at vente længere. Under sit møde i dag har U.A.C. nu alvorligt og grundigt overvejet det foreliggende spørgsmål om en visitation, og er, efter at nogle hindringer her på stedet har kunnet fjernes, nået til den beslutning at foretage et sådant besøg endnu $i$ dette år $i$ håb om, at Herren $i$ nåde vil give sin velsignelse dertil. Broder Ernst Reichel ${ }^{15}$ er blevet betroet med denne opgave og har erklæret sig villig til at overtage den. Han er ikke ukendt med menigheden i Christiansfeld, siden han har været der som kapellan". ("Brüderpfleger").

Den $\mathrm{i}$ brevet nævnte nyeste konvention kan kun hentyde til konventionen $i$ Gastein af 14 . august 1865 , hvorved frllesadministrationen af hertugdømmerne blev afløst på den måde, at Prøjsen overtog Slesvigs, Østrig Holstens administration. Om denne konvention blot har været anledningen eller den egentlige grund til U.A.C.S beslutning, må stå hen. Så meget synes dog at være klart, at styrelsen hermed har foretaget det første skridt hen imod en forståelse. I denne sammenhæng er det vist også bemærkelsesværdigt, at det er Ernst Reichel, der skal repræsentere U. A. C., ikke Tietzen, der som Christiansfelds decernent ellers ville have været nærmest dertil. Men Tietzen har under forhandlingerne ved sin stejle holdning øjensynligt mistet den tillid, en forhandler måtte være $\mathrm{i}$ besiddelse af.

Hvor lidt vægt de danske i Christiansfeld har lagt på landsregeringens svar, fremgår allerede deraf, at dennes "Eröffnung " først så sent bliver sendt til Aastrup. Hovedinteressen samler sig nu om den forestående visitation.

Østers næste brev til Aastrup er dateret den 4. oktober. Skønt det er ret langt, gengives det her så godt som fuldstændigt: 
»Først beder jeg dig undskylde, at det har trukket sig så længe hen, førend jeg tilskrev og sendte dig indlagte "Eröffnung ", som vi har modtaget som svar på vores andragende. Du vil indse, at det i grunden er betydningsløst, dog tænker jeg, det vil kunne være os lidt til nytte. Vores klage er ubegrundet, altså frakender øvrigheden sig og amtmanden al skyld for din afsxttelse og fremstiller vores direktion som den, der bærer skylden. Afsættelsen billiges ikke, og hvis amtmanden havde været årsag, ville sågar landsregeringen ikke have kunnet undgå at sætte ham under tiltale. Ved den forestående visitation kan vi altså påstå, at skylden for din afsxttelse hviler på U. A.C. og kunne om fornødent bevise det ved skrivelse fra regeringen, dog ville jeg helst, at skrivelsen ikke blev lagt frem, da den derved let taber den vigtighed, vi ellers tillægger den. Du kan nok tænke, at broder $\mathrm{E}$. Reichels forestående visitation danner hovedpunktet i samtalerne her $\mathrm{i}$ byen $\mathrm{i}$ denne tid. Vi ønsker så meget som muligt at give ham et klart indblik $i$ vores forhold, idet vi håber, at sandhedens magt selv vil bidrage til at oplyse ham, om han også kommer hertil med mange fordomme. Hovedsagen er, at manden vil høre og antage sandheden. Eet punkt håber jeg, vi vil kunne opnå, olstuens lukning, vi har gjort så mange sørgelige erfaringer af den ånd, der regerer $\mathrm{i}$ denne stue og opfylder den ene broder med et sådant had mod den anden, at han bliver medbrødres angiver, ${ }^{10} \mathrm{ja}$, at gendarmer selv har sagt, når de blev tiltalt over deres fremfærd, at det var vores egne folk, som ikke ville lade dem have fred, for de optrådte så skarpt mod byens indvånere. Dertil er vi jo aldeles $i$ overensstemmelse med menighedens principper, når vi forlanger en sådan skænkestue lukket. For mig som for flere er den fremfærd, som er vist mod dig, hovedpunktet, og det er også ved den, der er anrettet den største skade $\mathrm{i}$ menigheden. Skønt jeg vel véd, at vi ikke kunne udrette noget, er det dog vor pligt endnu engang at tolke for Reichel al den sorg og den forstyrrelse i Herrens gerning, $\mathrm{i}$ hjerternes ro såvel som $\mathrm{i}$ tilliden til unitetet, den forargelse, der blev givet vores hele omegn ved så at sige at fordrive dig fra vores forsamlinger, alt dette bør vi endnu engang fremføre for Reichel og tillige det ansvar, U. A. C. har pålagt sig ved en så overilet aldeles umotiveret indgriben $\mathrm{i}$ Herrens gerning $\mathrm{i}$ vor menighed og sammes omegn. Jeg håber dog ikke at kunne skade dig ved en sådan udtalelse, jeg håber med Guds hjælp, at det skal ske $\mathrm{i}$ en broderlig og 
rolig tone. Også Kaftan og Wolffs ${ }^{10}$ udelukkelse, hvortil Aufseher Collegium nægtede sit samtykke, men som alligevel ved befaling fra U. A.C. gennemførtes, bør vistnok fremhæves som et tegn på, at de danskes forseelser dømmes langt hårdere end $\mathrm{i}$ forrige tider de tyskes, og at det desværre ser ud for os, som det var langt mere brødremenighedens opgave at udbrede den tyske nationalitet end Guds rige. Bönhof har jo vist sig $i$ et sådant lys, at det ikke kan undgås, at der bliver adskillige kendsgerninger om ham at anfore. At Garve sender usande beretninger til U. A. C., er os vist alle bekendt, og fremgangsmåden mod Wolff og Kaftan viser det tydeligt, også her udgjorde han alene sagen uden at foredrage den $\mathrm{i}$ den samlede konferenz. Vi frygter meget, at Jacobsen nu også skal bort, når jeg skal sige min private mening, tror jeg, at han engang gerne ville have gjort en svingning, men det blev ikke antaget for gyldig, og nu er han nødsaget til at følge med os, sønnens nærværelse har vel også bidraget lidt dertil; Jacobsen interesserer sig nu meget for, at Reichel ret kan få sandheden at vide. Garve er ved mange lejligheder næsten uforskammet mod ham. Da sønnen tog afsked, sagde Garve: Dine forældre rejser vel snart efter dig til Amerika? Sønnen mente nej, det havde de ikke lyst til, en sådan flytning ville også koste meget. Garve svarede, når de solgte deres hus, kunne der jo nok blive penge til rejsen, og her var forholdene meget ubehagelige for dem. Jeg synes, det var tegn nok til, hvor gerne han ville af med dem. Sådant, tænker jeg, kan også opfylde dig med glæede, at du ikke længere er her og udsat for de mange ubehageligheder, som omgangen med sådanne folk nødvendigt må medføre.

Hvad vores rejse til København angår, da har du vist allerede for længe siden af bladene hørt beskrivelse om samme. Den var ganske overordentlig behagelig, alt forenede sig for at gøre den så opløftende og højtidelig som mulig, den vil aldrig glemmes af os, den var et nyt bevis for, at vi hører hjemme i Danmark, at vi aldrig ville føle os hjemme $\mathrm{i}$ noget andet land eller under anden regering end den danske, hvad Gud har sammenføjet, kan menneskene ikke adskille. Københavnerne viste os nu mageløs gæstfrihed, det var $\mathrm{i}$ sandhed festdage for slesvigerne, og på ny fik vi vist alle mod til at stå fast på vor post som danskhedens forkæmpere mod syd. Var der også enkelte timer som $\mathrm{i}$ teater og deslige, som ikke interesserede os så meget som de andre, så var ånden, der besjxlede selskabet på 
hele rejsen og ligeledes vore sjællandske værter, så god og hæderlig, ja en sand venskabs og kærligheds ånd, at den ikke kan andet end efterlade et godt og behageligt indtryk, og jeg har heller ikke i mit indre fundet mindste bebrejdelse over min deltagelse i denne rejse".

Den nationale splid i Christiansfeld var selvfølgelig ikke bragt ud af verden med Aastrups forflyttelse til Gøteborg. Tværtimod var de danskes forbitrelse vokset, og svælget mellem danske og tyske $\mathrm{i}$ Christiansfeld var blevet endnu dybere. Ernst Reichels opgave har abenbart været at mægle mellem de to partier for om muligt at genskabe det tidligere forhold af gensidig broderlig tillid.

Udelukkelsen af Kaftan og Wolff, som nævnes i brevet, forudsætter, at Aastrup er bekendt med sammenhængen. Ifølge protokollen i Christiansfeld af 22. august 1865 havde Kaftan båret nationale farver. En tysk gendarm havde forlangt, at han skulle fjerne dem. Det havde Kaftan nægtet, og nu havde Wolff »unberufener Weise « blandet sig i sagen og brugt skxldsord. Derpå havde gendarmen arresteret dem begge, men de havde nxgtet frivilligt at folge med.

Garve har øjensynligt indberettet sagen til sine kirkelige foresatte i Berthelsdorf og af disse fået besked om, at "vogterne over menighedsstatutterne", "Aeltesten Conferenz" og "Aufseher Collegium" "skyldte Herrens ære at udelukke de to brodre fra menigheden «. "Aeltesten Conferenz « samstemte med U. A. C., men i "Aufseher Collegium « var der majoritet for blot at udelukke dem fra nadverfællesskabet. Det tog U. A. C. imidlertid ikke notits af, men dekreterede, at de to oprørske brødre skulle udelukkes af menigheden.

Bönhof, som kort er nævnt, var kapellan ("Brüderpfleger»), og det var $\mathrm{i}$ øvigt ham, der førte den gentagne gange her anførte protokol i Christiansfeld.

Rejsen til København er identisk med sønderjydernes kendte besøg i København. Om denne rejse hedder det $\mathrm{i}$ det følgende brev fra Oster til Aastrup, dateret den 19. november:

"Da vores samtale begyndte, ville han (Reichel) irettesætte mig for min deltagelse $i$ turen til København, fordi jeg derved havde krænket mine søskende og taget del $i$ en demonstration. Jeg sagde, at rejsen havde været mig meget behagelig og ville stå således $\mathrm{i}$ inin erindring, så længe jeg levede, men den var ikke sket for at bedrøve nogen, men Danmark ville jeg stedse anse som mit fxdreland, og hvis forholdene både $i$ landet og særdeles $i$ menigheden skulle ved- 
blive at være som hidtil, ville jeg ikke kunne blive her. På hans spørgsmål, hvor jeg tænkte at drage hen, fortalte jeg, at vi helst ønskede at danne en menighed i Jylland, og hvis U. A. C. ikke ville understøtte et sådant foretagende, agtede vi at slutte os til den engelske provins«.

En anden bemærkning af samme brev viser en betydelig realitetssans, men samtidig en urokkelig tro på, at Christiansfeld igen ville blive dansk. Den lyder:

"For øjeblikket synes mig, er udsigterne til vore ønskers opnåelse atter her at blive dansk, ikke store, men det kan jo derfor ske, for man tænker. Endnu ville jeg spørge dig, om du mærker stor deltagelse for os og vor sag i Gøteborg. G. er vel et hovedsted for skandinavismen? «

Hovedindholdet af det ret udførlige brev er en beretning og vurdering af Ernst Reichels besøg. Han får det vidnesbyrd, at han »har frembragt indtrykket af en retskaffen mand, som ønsker at kende sagerne, som de er «. Et andet sted hedder det ganske vist: „Reichel er vist en klog mand og forstår altid på en juridisk måde, om jeg så tor sige, at komme bort fra de ubehagelige sandheder...

De danskes håb om ved denne lejlighed at få lukket brødrehusets ølstue blev ikke opfyldt. Reichel erklærede, at det ikke faldt under hans kompetence, men måtte afgores af de stedlige myndigheder. Disse fandt (iflg. protokollen), at der ikke havde varet tale om tilfælde af "egentlig uorden «, men at kravet blot var rejst af nationale grunde. De fandt derfor ingen anledning til at lukke lokalet.

\section{Adressen om $\S 5$.}

Desværre findes ingen breve til Aastrup fra året 1866. Det er så meget mere beklageligt, som netop dette år med Prag-fredens $\ 5$ bragte et for Christiansfeld ligesom for hele Sønderjylland afgørende moment ind i billedet. Først fra begyndelsen af 1867 foreligger igen to breve til Aastrup. Vi kan imidlertid følge udviklingen ved hjælp af andre kilder, suppleret af notater $i$ Christiansfelds protokol og enkelte breve mellem Christiansfeld og U. A.C.

Som bekendt havde Napoleon III allerede i præliminærfreden $i$ Nikolsburg og senere i Prag-fredens bestemmelser fået indført den berømte $\S 5$, hvorefter den nordlige del af hertugdømmet Slesvig skulle tilbagegives til Danmark, hvis en folkeafstemning gav flertal 
herfor. Denne bestemmelse vakte naturligvis entusiastisk forventning hos Sønderjyllands danske og skabte vild rædsel blandt den tyske minoritet. Derom vidner et protokollat af 8 . august, der indrømmer, at der næppe kan være tvivl om resultatet af en sådan afstemning. Hvor tysk orienteret den lokale korporation var, fremgår af, at der var tale om at lykønske den prøjsiske konge til sejren ved Königgrätz, hvad man dog afviste. Derimod foreslog man at bede U. A.C. henvende sig til kongen af Projsen, for at denne gennem hoffet i København skulle opnå, at brødremenighedens gamle privilegier, navnlig tysk kirke- og skolesprog, måtte blive fornyede.

Så moderat dette forslag ser ud, da det jo i virkeligheden blot tilsigter en yderligere garanti for, hvad brødremenigheden i Christiansfeld havde fået bevilget i 1772, viser det dog, i hvor høj grad også de tyske kredse i Christiansfeld ventede Sønderjyllands tilbagevenden til Danmark efter en folkeafstemning. Som vi senere skal se, havde den danske regering nemlig i 1859 villet indskrænke disse privilegier, og man anså det nu for det højest opnåelige at kunne beholde, hvad man tidligere havde haft.

Det varede ikke længe, før tyskerne fra denne defensive holdning gik over til direkte angreb. I Aeltesten Conferenz' protokol af 20. august hedder det, at Garve den 15. august om formiddagen havde modtaget et telegram fra herredsfogeden med opfordring til snarest muligt at møde til audiens hos civilkommissarius for hertugdømmet Slesvig, friherre von Zedlitz, der befandt sig i Haderslev på gennemrejse. Brødrene Garve og Jacobsen havde fulgt denne opfordring og var i Haderslev truffet sammen med von Bülow. Overfor disse tre havde friherre von Zedlitz udtalt onsket om, at der også fra Christiansfeld måtte afgives en erklæring om, hvorvidt et yderligere regeringsskifte syntes at være ønskeligt for menigheden eller ej. I en så vigtig sag havde man ikke turdet handle på egen hånd, og derfor havde Garve udbedt sig forholdsregler fra U. A. C. Dem ventede man nu spændt på.

Få dage senere, den 31. august, beretter samme protokol, at Garve den 24. august har fàet besøg af herredsfoged Selig (altså dagen efter fredsslutningen i Prag). Selig havde da anmodet om, at adressen, hvis forelæggelse oprindeligt havde været berammet til den 27. august, måtte blive fremskyndet. Samtidigt havde han stillet $\mathrm{i}$ udsigt, at de tysksindede borgere i Christiansfeld ville blive opfordret 
til at affatte en sådan adresse, dersom menighedens direktion ikke gjorde det. Endelig havde Selig forlangt, at adressen skulle forsynes med navneunderskrifter, hvad der oprindeligt ikke havde været tale om.

U. A. C. har hurtigt svaret på Garves brev. I svarskrivelsen hedder det (i oversættelse):

"Det ville have været meget ønskeligt, og det ville have svaret til vor karakter som brødremenighed, hvis Christiansfeld i spergsmålet om dens politiske fremtid kunne have holdt sig helt stille og måtte have nøjedes med at se til, hvorledes Herren vil føre det, han som også holder kongernes hjerter i sin hånd. Så ville man også have undgået ethvert skin af partiskhed. Og hvis der ikke nu fra regeringens side var kommet en opfordring til en erklæring, gennem hvilken man på en måde bliver gjort ansvarlig for fremtiden, da måtte vi fremdeles tie. Og ligeså endog trods en sådan opfordring, hvis det her alene drejede sig om opfyldelsen af nationale eller merkantile ønsker og om spørgsmålet: Vil I hellere kaldes danske end tyske. En handling til opnåelse af sådanne formål ville betyde at drive politik og forarge den broder, der havde en anden opfattelse. Det må vi ikke. Men vi må her holde øjet åbent for en anden og vigtigere opgave, som helst skulle ligge alle sande menighedsmedlemmer lige meget på sinde: Christiansfelds vel og opretholdelse som brødremenighed. Selv om brødrene fra gammel tid har holdt sig borte fra al politik, så har de dog ikke ladet hænderne ligge i skødet og bare afventet, f. eks. ved anlæggelse af nye menigheder, om en concession ville blive dem tilbudt, men de har ansøgt om den, og for at få fat $\mathrm{i}$ vore privilegier har vi indgivet petitioner derom o.s. v. Hvis nu menigheden i Christiansfeld hele tiden havde stået $\mathrm{i}$ samme forhold til den danske regering som indtil den sidst afdøde konges regeringstiltrædelse, d.v.s. i den uforstyrrede besiddelse af sin concession, så ville man heller ikke i dag have anledning til at udtale sig og kunne roligt afvente fremtiden $i$ den overbevisning, at menigheden ville kunne nyde samme velvilje fra den ene som fra den anden regering. $\mathrm{Nu}$ må imidlertid erfaringerne efter 1848 indgyde nogle bekymringer for menigheden Christiansfeld under dansk regering. Vi har siden da trods gentagne bønner ikke mere fået nogen concession $i$ hænde. Der har været tale om obligatorisk indførelse af dansk kirke- og skolesprog, hvad der på grund 
af mangel på duelige personer ville bringe os $\mathrm{i}$ den største forlegenhed. Der er blevet henvist til kravet om præsentation og godkendelse af vore tjenestemænd ved regeringen (jfr. forhandlinger med amtstuen i Haderslev af året 1859), hvorved fremtidsmulighederne for menigheden som sådan kunne sættes på spil. Om Christiansfeld under genforening med Danmark ville blive restitueret in statum pro ante 1848, derfor har vi ingen som helst garanti, medens Prøjsen allerede uopfordret har bekrxftet concessionen, og selv om denne også nu ville gøre en yderligere bekræftelse nødvendig, kan vi ikke være i tvivl om, at denne menighed ville få de samme friheder som de andre prøjsiske menigheder. Dette er overvejelser, som man ved denne lejlighed ikke kan se bort fra, og som man må tage hensyn til ved spørgsmålet, om man nu skal tale eller tie.

Et andet spørgsmål er, hvem det tilkommer at afgive en sådan erklæring, hvis den altså skal afgives. Regeringen ønsker i denne omgang ingen folkeafstemning, men en udtalelse af myndighederne. U. A. C. synes, at Christiansfelds Aeltesten Conferenz alene ikke kan være berettiget dertil. Den er indsat af U. A. C., men ikke den af beboernes tillid valgte myndighed. U. A. C. anser Aeltesten Conferenz i fællesskab med Aufseher Collegium for det kompetente forum, hvor Aufseher Collegium består af menighedens tillidsmænd. Det således sammensatte collegium - mener U.A.C. - må nu overveje, om det vil tie, eller om det overfor hr. von 'Zedlitz vil udtale, at en yderligere regeringsændring - thi nu er den faktisk prøjsisk - ikke vil være ønskelig for menigheden.

Hvis Aeltesten Conferenz og Aufseher Collegium ikke kan beslutte sig til at overtage ansvaret herfor, måtte Gemeinrat ${ }^{17}$ spørges. Men vi beder dog betænke, at denne forholdsregel ville medføre en storre ophidselse og lejlighed til agitation, og at menighedsspørgsmålet - hvad der ville være en ulykke - kunne blive forvandlet til et politisk eller nationalt spørgsmål.

Angående jeres onske om, at der i tilfxlde af en tilbagelevering til Danmark måtte foretages noget for opnåelsen af en concession, så ville den, forudsat at en erklæring fra jer til hr. von Zedlitz bliver afgivet, lettest lade sig gennemføre ved til afslutning at bemærke: Skulle det vise sig umuligt, at Christiansfeld forbliver under prøjsisk regering, så bad man underdanigst om, at der ved de forestående forhandlinger blev virket henimod, at menigheden atter 
blev indsat $i$ sine gamle privilegier ved en ny concession af varig gyldighed.

Om denne sags yderligere forløb beder jeg dig indgive beretning, men foreløbig at signalisere mit brevs rigtige modtagelse ved en hvilken som helst tryksag til min adresse «.

Hvad man umiddelbart føler sig ilde berørt af, er brevets opfordring til at "signalisere" den rigtige modtagelse ved en anonym postforsendelse. Det minder lovlig stærkt om hemmelige aftaler mellem sammensvorne.

I øvrigt synes brevet bestræbt på at holde en neutral linje. Det er, siges der, ikke politiske eller nationale sympatier, som taler imod en genforening af Christiansfeld med Danmark, men ganske bestemte reale forhold. De gamle privilegier, som Struensee i sin tid havde indrømmet herrnhuter-kolonien, er 1859 blevet truede på en måde, der bringer byens status som brødremenighed $\mathrm{i}$ fare. Bare det ikke havde været tilfældet, kunne man $\mathrm{i}$ dag med samme frimodighed som 1772 have føjet sig under en hvilken som helst regering, hvad enten den var dansk eller tysk. Ud fra vor tids syn kan man måske beklage de krav, som af den danske regering blev stillet, og som nok kan smage af en småsindet hævnakt overfor al tyskhed, der bød en billig argumentation til fordel for U. A. C.s bedømmelse.

Der har næppe været nogen bevidst usandhed i disse betragtninger. Det er blot ikke taget $i$ betragtning, at nationalitetsprincippet både $\mathrm{i}$ Danmark og $\mathrm{i}$ Tyskland havde afstedkommet meget forandrede synspunkter. De danske krav indskrænker sig til det rent nationale uden på nogen måde at berøre herrnhutismens religiøse indhold. Havde brødremenigheden ved grundlæggelsen af Christiansfeld ikke varet i stand til at løse sin opgave uden sine egne tysktalende embedsmænd, så skulle det $\mathrm{i}$ mellemtiden formentligt have været muligt i Danmark at finde egnede personer til sagens videreførelse. Ikke mindst blandt gamle danske præsteslægter (Balslev, Boesen, Hammerich, Windekilde) var der en nær tilknytning til Christiansfeld. Man kan da dårligt frigøre sig fra den tanke, at den nationalitetsbevidsthed, som den danske regerings krav vidner om, også har gjort sig gxldende hos herrnhuternes ledende tyske mænd, og at den mere eller mindre bevidst er faldet godt $i$ tråd med deres argumentation.

Om man vil, kan man kalde disse overvejelser svævende gisnin- 
ger, som man ikke kan bygge ansvar eller angreb på. Men sådan forholder det sig ikke med det væsentlige indhold af $\S 5$, der tilstod den nordligste del af Slesvig ved en folkeafstemning selv at afgøre det fremtidige tilhørsforhold. Bismarck har senere erklæret, at denne paragraf i Prag-freden kun vedrørte Prøjsen og Østrig, men ikke Nordslesvig, men denne juridiske spidsfindighed lå lige langt fra både dansk og tysk opfattelse, da erklæringen skulle afgives. Da drejede det sig om det simple spørgsmål, om et givet ord skulle holdes eller ikke. Efter almindelig retsbevidsthed var det et klart løftebrud at forhindre afstemningen.

Det var altså her, valget $\mathrm{i}$ virkeligheden lå: Skulle U. A. C. selv forudsat, at man virkelig frygtede, at Christiansfelds genforening med Danmark ville få uheldige virkninger for brødremenigheden - godkende, hvad de danske brodre i Christiansfeld med rette måtte betragte som et groft løftebrud. Man kommer næppe uden om det indtryk, at herrnhutismens tidligere heroiske tro er stærkt blandet med menneskelig beregning og national sympati.

Fremskyndelsen af tyskernes $\mathrm{krav}$ om aflevering af erklæringen må formodentligt have umuliggjort at følge den af Tietzen foreslåede fremgangsmåde, hvorefter Aeltesten Conferenz først skulle sætte sig i forbindelse med Aufseher Collegium og evt. Gemeinrat, men den har øjensynligt bestyrket Aeltesten Conferenz i den opfattelse, at de havde U. A. C.s billigelse i ryggen. Det pludselige hastværk fra tyskernes side straks efter Prag-freden kan næppe forklares på anden måde, end at sagen skulle piskes igennem, så at tyskerne i Sønderjylland ikke fik tid til at tænke sig om, men helt udleverede sig til ubetinget følgeskab, medens danskerne skulle afskæres fra enhver rettidig modaktion.

Den tyske adresse fra Christiansfeld blev afleveret til den berammede tid og havde folgende ordlyd (i oversættelse):

»Allerdurchlauchtigste stormægtige konge, allernådigste konge og herre!

Deres kongelige majestæt bedes allernådigst tillade de forordnede repræsentanter for brødremenigheden Christiansfeld at nærme sig Deres majestæts allerhøjeste trone $\mathrm{i}$ dyb xrbødighed for at hilse Deres majestæt som trofaste undersåtter og underdanigst at udtale vore ønsker. Som det er Deres majestæt bekendt, holder brødremenigheden sig principielt borte fra al politik, forholder sig helst stille 
og glæder sig kun over at kunne se til, hvorledes Herren, den almægtige, styrer skæbnen, og er den af ham indsatte øvrighed af hjertet underdanig. En sådan øvrighed ærer vi så meget desto mere taknemligt i Deres majestæts regering, som den allerede velvilligt har tilstået os vor brødremenigheds concession og dermed de privilegier, uden hvilke den ikke kan bestå, og vi stoler - under Deres majestxts beskyttelse - så meget mere frimodigt og glad på Guds velsignelse, som også vi sammen med hele den forbavsede verden har set, hvordan hærskarernes Herre vedkender sig Deres majestæt, hvordan han har ført Deres majestæts hære fra sejr til sejr, og hvilke vældige gerninger han har udført.

Da tør også vi, med nyt mod til at fremlagge vore ønsker, ikke tie, og vi fremlægger for Deres majestæt vore inderligste ønsker om lykke og velsignelse med den inderlige bøn til Herren om, at han også fremdeles - lige som hidtil - vil være med Deres majestæt, men også at han vil vejlede Deres majestæts hjerte til ikke at overlade os til en fornyet uønsket forandring i regeringen og tillade vor brødremenighed fortsat at måtte nyde vore privilegier med tysk kirke- og skolesprog under Deres majestæts velsignede scepter sammen med vore tyske brødremenigheder, af hvilke de fleste befinder sig i Deres majestæts stater, og dér føler sig lykkelige.

Deres majestzets allerunderdanigste og trofast lydigste undersåtter, brødremenigheden Christiansfelds repræsentation i navn og på mandat af dennes majoritet.

Christiansfeld, 26. august 1866.

L. Garve, præst.

Andr. Jacobsen, menighedsforstander.«

En sammenligning af Tietzens brev med den udformning, som Garve gav adressen, er ganske interessant. Garve har i det store og hele ret nøje fulgt linjen, der var lagt af styrelsen $i$ Berthelsdorf. Den meget devote tone, der går gennem skrivelsen, skal man nok ikke hæfte sig for meget ved. Den svarer til, hvad der dengang i Prøjsen i sådanne tilf xlde var det almindelige. Derimod kan man nok spørge, om det var nødvendigt for Garve at understrege det trofaste undersåtforhold i Christiansfeld så stærkt. Hvor Tietzen blot taler om at "se til, hvorledes Herren, der også holder kongernes hjerter i sin hånd, " bliver det i Garves redaktion til "glæde over 
at kunne se, hvorledes Herren, den almægtige, styrer skæbnen, og at man er den af ham indsatte øvrighed af hjertet underdanig «. Særdeles usmageligt virker det, når han taler om, at »hærskarernes Herre vedkender sig Deres majestæt ved at føre Deres majestæts hære fra sejr til sejr" (sejrene i Østrig, der førte til Prag-freden, hvis paragraf 5 dog åbenbart ikke regnes med til Guds »vældige gerninger $*$ ).

Bortset fra disse stilblomster, som Garve har tilføjet for egen regning, må man dog vist anerkende, at adressen $\mathrm{i}$ formen er korrekt. Den foregiver ikke at tale på alle borgernes vegne, men "i navn og på mandat af majoriteten $\mathrm{i}$ brødremenighedens repræsentation «. Kedeligt er det blot, at næppe nogen ville komme $i$ tanker om, at denne majoritet ikke var identisk med hele borgerskabets - hvad det vel heller ikke netop var tilstræbt, at man skulle.

De dansksindede i Christiansfeld var naturligvis forfærdede ikke alene over selve adressen og dens indhold, men måske $i$ endnu højere grad over, at U. A. C. støttede den. Det blev naturligvis ikke bedre af det indtryk af forjagethed, som hele aktionen havde fảet. Men hvis det virkelig var de tyske embedsmænds hensigt, at der ikke skulle levnes danskerne tid til at tage stilling, endsige at foretage en modaktion, havde de $\mathrm{i}$ alt fald for Christiansfelds vedkommende taget fejl.

Her lå sagen endog dobbelt tung. Det afgørende for dem var, at U. A.C. med sin autoritet ikke måtte stå bag adressen, og man måtte derfor prøve at påvirke styrelsen $\mathrm{i}$ den modsatte retning. Korrespondancen mellem Herrnhut og Christiansfeld tog sin tid. Skulle der udrettes noget, måtte der handles lynsnart. Allerede fra 24. august, altså samme dag, som Selig havde forlangt sagens fremskyndelse, foreligger udkastet til et brev fra $\varnothing_{\text {ster til Ernst Reichel }}$ i U. A. C. Der hedder det (i oversættelse):

\section{-Kare broder Reichel!}

Ved din tilstedeværelse her gav du mig lov til enhver tid frit at henvende mig til dig, og derfor håber jeg, at du også nu vil optage disse linjer i kxrlighed. Trængslernes tid for vort kxre Christiansfeld er, som det synes, endnu ikke forbi. Er det ene stød overstået, og sindene er ved at falde til ro, følger straks et endnu hårdere. Kan noget stød være hårdere end det, at vore "fædre ${ }^{18}$ og lederne 
af hele vort brodrefolk viser os, at de mere forlader sig på mennesker end på Herren, at alt, hvad der siges os, blot er tomme ord, der kan være gode til at styre menigmand?

Du kender efter dit besøg i sidste efterår bedst forholdene og personerne her, og derfor håber jeg, at du i det nuværende kritiske øjeblik vil låne øre til de danske søskendes bekymringer og ønsker. Fra tysk side vil embedskorrespondancen give jer tilstrækkelige meddelelser. Efterretningen om, at Nordslesvig igen skulle komme til Danmark, har naturligvis glædet os meget. Med hensyn til afstemningen har vi været ganske rolige, fordi vi ved, hvor stort de tysksindede indbyggeres "flertal « er. Så meget mere har det bedrøvet mig at erfare, at der af U. A. C. er foretaget skridt for at opfordre os til selv at medvirke ved afgørelsen af vor skæbne...

Jeg ved, at flere danske søskende har ladet sig holde borte fra deltagelsen i politiske demonstrationer, og det synes også virkelig, som om de tyske søskende ville holde sig udenfor, idet både Aufseher Collegium og Conferenz ikke ville indgive en adresse til kongen af Prøjsen, men desværre har I ment at skulle indvirke $i$ modsat retning...

$\mathrm{Vi}$ er meget bange for, at I også ved korrespondancen herfra er blevet tilskyndet til sådanne skridt. Men vi, de danske søskende, beder, at I dog også vil tænke på os med kærlighed, og at der måtte være en lille plads $\mathrm{i}$ jeres hjerte også for os, for trods alle forskelligheder $\mathrm{i}$ de ydre ting, foler vi os som lemmer af menigheden dog forbundne med jer. Vi ville så gerne, at den tillid, som ved dit besøg, kære broder Reichel, igen var styrket noget, ikke atter måtte blive helt sønderrevet. Vi beder jer ikke her at gå $i$ en fælde, som embedsmændene har stillet op for jer. Vi frygter, at I bliver udbyttet af folk, der aldeles ikke er interesseret $i$ vor sag, men kun tænker på sig selv og deres eget. Broder Garves store venskab og bekendtskab med embedsmændene i Haderslev er ikke af det gode, og når en sådan adresse bliver nærmere kendt $i$ vor omegn, vil det atter fremkalde meget fjendskab mod os og sætte menigheden $i$ et dårligt lys, ja, mange søskende fra diasporaen vil igen tage forargelse og vende sig bort fra os. De kan virkelig ikke tro andet, end at vi er et dødt ådsel, som ånden er veget bort fra, når vore handlinger går stik imod vor lare.

Kære broder Reichel, hvis der endnu er en mulighed for, at dette 
skridt med adressen kan tages tilbage, så gør det! Telegrafen kan jo hurtigt bringe jeres ønsker hertil. Vi ville så gerne, når det her bliver dansk igen, møde jer og vore gamle indretninger $\mathrm{i}$ kærlighed og bevare dem, men dertil trænger vi også til imødekommenhed fra jeres side, og det beder vi om. Vi vil foreløbigt være helt stille og ikke lade noget komme ud til de andre søskende, men skulle I fremdeles bestå på, at adressen skal afsendes $\mathrm{i}$ tyskvenlig tendens, ville vi ikke kunne undgå også at sende en dansk adresse til kongen af Prøjsen ...

Udkastet til dette brev er underskrevet af Øster. Ernst Reichels brev, der, uvist af hvilken grund, er rettet til S. Christoph, lyder (i oversættelse):

»... Vi har i U. A. C. alvorligt drøftet indholdet af jeres brev, men kunne dog, forudsat at et telegram endnu kunne have nået rettidigt frem, ikke fravige vor $\mathrm{i}$ et tidligere brev udtalte mening. Vi ville have været imod enhver petition, både $\mathrm{i}$ den ene og den anden retning, hvis den var blevet foreslået af egen fri vilje $i$ den overbevisning, at det ikke kunne være vor sag. Men da nu jeres menighedsdirektion af den prøjsiske øvrighed blev opfordret til en sådan erklæring, og ansvaret for de følger, undladelsen kunne føre med sig, blev skubbet over på denne direktion, mente vi at skulle tilråde at give efter, således at Aeltesten Conferenz sammen med Aufseher Collegium i menigheden (forudsat, at de onskede at blive under det nuværende prøjsiske regimente) lod erklæringen gå til regeringen som denne korporations eller dens flertals ønske.

Vi har ved at give dette råd, det tror jeg, jeg kan sige, slet ikke ladet os influere af nationale sympatier, vi ville, hvis vi alene havde kunnet se tilbage til de tidligere årtier, da Christiansfeld stod under dansk scepter, afgjort have frarådet et sådant skridt $\mathrm{i}$ den overbevisning, at I som brødremenighed kunne befinde jer lige godt under den ene som under den anden regering. Men desværre har de sidste år belært os om, at Christiansfelds beståen som brødremenighed med sin forfatning og i sammenhæng med de øvrige menigheder, d.v.s. jeres menigheds højeste interesser, ville være alvorligt truede, hvis den igen blev forenet med Danmark. Som bevis herfor vil jeg kun anføre det ene faktum, at der under 1. august 1859 fra amtstuen i Haderslev blev afgivet en erklæring til menighedsdirektionen, hvori det hed, at en stadfæstelse af vor menigheds koncession 
kunne vi kun håbe at opnå med følgende indskrænkninger: 1) at de af U.A.C. kaldede tjenestemænd skulle stadfæstes af regeringen, før de tiltrådte deres embede, 2) ligeså lærerne overfor skolemyndighederne, 3) at kirkesproget skulle være overvejende dansk, 4) at skolerne på alle måder skulle være underkastet skolemyndighedernes tilsyn (bl. a. med hensyn til undervisningsbøger). Sådanne følger må og kan vi overlade til Herren, hvis det skulle behage ham atter at give menigheden i Christiansfeld tilbage til Danmark, men på samme måde synes pligten at påbyde os, at hvis menighedens repræsentanter delte vor overbevisning, og da det af regeringserklæringen var lagt $\mathrm{i}$ deres hånd ved ytring af deres onske at forebygge sådanne følger, der måtte forudses ved afståelsen til den danske krone, da måtte de $\mathrm{i}$ menighedens sande interesse tage dette ansvar på sig. Det hviler meget tungt på os, at partiånden derved muligvis på ny vækkes i menigheden selv, og ligeså at mange af vore kære diasporasøskende tager forargelse af os, fordi de ikke kan forstå vore motiver; men det er der ikke noget at gøre ved. Hvad angår

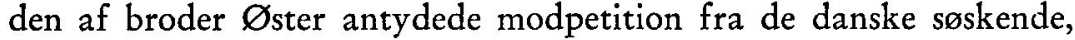
så kan jeg kun sige: Gør, hvad I mener at kunne forsvare for Herren og jeres samvittighed. Men $\mathrm{i}$ fredens interesse indenfor menigheden må jeg dybt beklage, hvis det sker, da der derved først for alvor ville blive hældt olie på ilden, og det let kunne foranledige en yderligere modpetition fra de anderledes tænkende. Måtte Herren $\mathrm{i}$ denne prøvelsestid forbarme sig over jeres menighed og tale så højt og indtrængende til alle dens medlemmer, at de hører hans røst, men måtte han også oplyse os, så vidt vi har at gøre med denne sag, med sin ånd. Dig og den kære broder Øster hilser i hjertelig kærlighed eders $\mathrm{i}$ troskab forbundne broder.

\section{Ernst Reichel.»}

De to breve synes at kræve et par kommenterende bemærkninger. De danske i Christiansfeld har åbenbart fået det indtryk, at deres lokale ledelse (Aeltesten Conferenz og Aufseher Collegium) har været imod at afgive nogen erklæring, men at U. A.C. nærmest har tvunget dem dertil.

Dette synes efter Tietzens brev til Garve (s. 163) - i alt fald $\mathrm{i}$ formen - ikke at være korrekt. Tietzen kræver netop, at myndighederne i Christiansfeld i et fællesmøde mellem Aeltesten Conferenz. 
og Aufseher Collegium, evt. endog Gemeinrat (bestående af menighedens voksne medlemmer) skal tage den afgørende bestemmelse. I sagen er det derimod ganske klart, at U. A.C. absolut ønsker, at adressen skal indsendes.

Reichel afviser ikke U. A. C.s ansvar, men han synes dog at afsvække det ved at understrege, 1) at U. A.C. ikke har pålagt, men blot tilrådet adressen, 2) at forudsætningen for dens afsendelse må være majoriteten $\mathrm{i}$ begge Christiansfelds ledende korporationer.

Protokollen i Christiansfeld giver ikke noget ganske klart billede. Man erfarer derved, at Garve straks har henvendt sig til U. A. C. uden først at forelægge sagen for Aeltesten Conferenz, og får det indtryk, at den af Tietzen foreslåede fremgangsmåde ikke er blevet fulgt, hvad den korte tidsfrist formentlig også ville have gjort meget vanskeligt. Det ser ud til, at Garve har handlet meget egenrådigt og blot forelagt den færdige adresse i Aeltesten Conferenz og faet dennes samtykke.

Den del af Reichels brev, som omhandler den danske regerings krav fra 1859, stemmer ret nøje overens med, hvad Tietzen har skrevet til Garve, bortset fra at disse krav er blevet trukket stærkere op. Men afgørende for de danskes reaktion har det selvfølgelig været, at også Reichel helt går uden om en omtale af loftebruddet med hensyn til $\S 5$.

Hele brevet gor det indtryk, at det ikke er skrevet med fuld overbevisning. Reichel har formodentligt ikke været glad for at skulle skrive det og nxppe følt sig sikker på, at de danske brødre ville være bange for at stå til ansvar for Gud og deres samvittighed, når de ikke ville købe fred på bekostning af ordholdenhed og ret.

Tre småstykker synes at være fremkaldt af Reichels brev. De lyder (i oversxttelse):

"Jeg ved ikke, om det er dig bekendt, at det for adressens tilblivelse har været afgørende, at en embedsmand skrev til broder Garve, takkede ham for hans hidtidige virksomhed for den tyske sag, men dernæst opfordrede ham indtrængende til endnu at tage dette skridt med adressen, idet han samtidigt bad om ikke at få sit navn nævnt. -

Det er slet ikke givet, at hvis det nu blev dansk, de samme betingelser ville blive stillet som $\mathrm{i} 1859$, og jo mere regeringen ved besked med, at der i Christiansfeld findes folk, som føler for den 
og den nationale udvikling, og som har vist dette $\mathrm{i}$ trængselstiderne, des lempeligere ville betingelserne blive. -

Men selv nu, da skolen helt er indrettet efter de tyske ønsker, og f. eks. et fag som Nordens historie er afskaffet, kan den ikke glæde sig ved de tyske nabopræsters bevågenhed. En af dem har udtalt sig meget nedsættende om den, mens det svigtende antal af elever viser, hvor lidt yndest det tyske væsen $\mathrm{i}$ almindelighed finder «.

Om disse tre brudstykker nogen sinde er blevet til et svarbrev til Reichel, er meget tvivlsomt. De tyder på, at et sådant svar har været påtænkt, men det er næppe blevet skrevet. Det ser nærmest ud til, at de danske patrioter helt har opgivet at vente noget som helst af deres tyske ledelse. I hvert fald findes der ikke flere henvendelser fra dem til U.A.C. Til gengæld har de øjensynligt fra nu af sluttet sig resolut sammen med den almindelige nationale bevægelse i Sønderjylland. En af Christiansfelds dansksindede borgere, Øster, var blandt $\gg$ De 47 «, der under Ahlmanns ledelse dannede deputationen i Berlin. Det lader til, at de ved denne lejlighed har medbragt den modpetition, som Reichel i sit brev havde søgt at forhindre, men som i øvrigt allerede havde foreligget færdig, før hans brev af 28. august nåede til Christiansfeld. Den er dateret den 29. august og lyder (i oversættelse): herre!

Fredspræliminarierne i Nicolsburg og eders kongelige majestrets ord til eders landdag i Berlin, at hvis befolkningen i Slesvigs nordlige distrikter ved en fri afstemning udtalte ønsket om genforening med Danmark, da ville eders majestæt føje dette ønske, har givet også os mod til at nærme os eders majestrts trone i dybeste xrbødighed for at overbringe vor dybtfølte tak for denne vise og æxelmodige beslutning, men tillige også for at udtale den underdanigste bøn om opfyldelsen af vore inderligste ønsker.

\section{Allernådigste konge!}

$\mathrm{Vi}$ ville ikke have vovet at træde frem for eders majestæt, hvis vi ikke havde været drevet dertil af den kendsgerning, at der også fra vor by er sendt en adresse i modsat retning af mænd, hvis majoritet ifølge deres fødsel ikke hører hjemme i Slesvig, og hvis borgerlige stilling til dels udelukker et frit og uafhængigt votum. 


\section{Allernådigste konge!}

Også i vor lille by Christiansfeld har de samme ønsker og håb rort sig som $i$ alle andre distrikter af Nordslesvig.

Det er ikke for ingenting, at vor by er blevet kaldt Christiansfeld. Under de danske kongers værn og milde regering er den vokset frem, og vi har altid følt os lykkelige under deres regimente, så at kærlighed og hengivenhed for Danmark og det danske kongehus har slået dybe rødder $i$ os.

At vor by blev anlagt $i$ en dansktalende egn, har sin dybe betydning, thi som brødremenighed dertil bestemt, blev den snart et samlingssted for de med den forbundne sjale fra den danske nation; men desværre har det $\mathrm{i}$ realiteten vist sig, at denne velsignelsesrige virksomhed er blevet væsentligt hemmet efter adskillelsen fra Danmark.

I samme mål som vor åndelige virksomhed er også vor materielle eksistens betinget af vor samhørighed med Danmark, og vi har måttet erkende, at ligesom hin er også denne alvorligt truet af den mellem hertugdømmerne og Danmark oprettede grænse, idet for tiden næsten alle forretninger mere eller mindre er gået $\mathrm{i}$ stå, så at adskillelsen også på denne måde føles smertelig.

Men endnu mere end alt dette er det den rost, som Gud Herren har nedlagt i menneskets hjerte, og som driver ham did, hvor hans stammefæller bor, der lærer os at elske det, som her på jorden er os det nærmeste, nationalitetens og blodbåndets røst, der vender vort øje mod nord og indgiver os den allerunderdanigste bøn, at eders majestæt allernådigst måtte behage at indløse eders allerhøjeste majestæts ord i så rigt mål, at det må blive os forundt sammen med hele Nordslesvigs befolkning ved en fri afstemning at give udtryk for vore sande onsker og selv træffe bestemmelse om vor endelige skæbne.

Allernådigste konge!

Vi beder til vor Herre og Frelser, at han rigeligt vil velsigne eders kongelige majestæt og hele det høje kongelige hus ud fra sin nådes rigdom og forbliver $\mathrm{i}$ dybeste $x$ rbødighed allerunderdanigst.

Christiansfeld, den 29. august 1866. 
Om end denne adresse ikke nåede frem til den projsiske konge ${ }^{19}$ og for så vidt ingen praktisk betydning fik for Christianfelds skæbne, fortjener den dog at blive stånde som et monument over de danske mænd, som gjorde hvad de kunne for den danske sag.

\section{Pressekampagne.}

Direkte henvendelse til de prøjsiske myndigheder havde vist sig at være håbløs. Derfor opgav man dog ikke kampen, men fortsatte på en anden front, idet man søgte at skabe en opinion for Sønderjylland i det tyske folk.

Bismarck var på den tid meget upopulær, ikke alene i de dele af Tyskland, som 1866 havde stillet sig solidariske med Østrig, men også i selve Prøjsen, hvor han havde hele den liberale opposition imod sig. Der fandtes aviser, som var mere end villige til at modarbejde hans politik. En af dem var "Kölnische Zeitung «. ${ }^{18}$

Allerede under 8. oktober 1866 nævner protokollen i Christiansfeld en artikel, der fornylig $i$ denne avis har rettet »svære, men uretfærdige og usande beskyldninger « mod Aeltesten Conferenz i anledning af dennes adresse til den prøjsiske konge.

Det drejer sig formodentlig om en artikel, der har indeholdt folgende afsnit (i oversættelse):

"Ved fredspræliminarierne i Nicolsburg blev der stillet beboerne i Nordslesvig i udsigt atter at blive forenet med Danmark, hvis de ved en fri afstemning tilkendegav ønsket derom. Siden da er der af Christiansfelds direktion og af enkeltpersoner $i$ byen foretaget skridt for at fremstille forholdene $i$ denne by over for den prøjsiske regering på en måde, som om brødremenighedens interesser var truet ved en genforening med Danmark, medens de var sikrede ved forbindelsen med Prøjsen. Flertallet af Christiansfelds borgere og indbyggere deler imidlertid ikke denne opfattelse. Den er under indflydelse og efter ønske fra højtstående embedsmænd udtalt af mænd, som for størstedelens vedkommende ikke er fødte slesvigere, som næsten alle er uden fast ejendom $i$ landet, og som derfor ingen berettigelse har $i$ en så vigtig sag at tale $i$ borgernes navn. De er ej heller vokset så snævert sammen med vor bys sande interesser, at de upåvirket af fremmede partihensyn kan repræsentere dem «.

At Aeltesten Conferenz ikke så en venlighed i disse udtalelser, er let nok at forstå. Derimod er det ikke så let at få øje på wuret- 
færdige og usande beskyldninger ". Conferenzen har iflg. samme protokol af 8. oktober drøftet spørgsmålet, om den skulle tage til genmæle. Det blev ganske vist afvist, men alligevel må der være fremkommet noget $i$ den retning, for det hedder videre $i$ et senere nummer af »Kölnische Zeitung « (i oversættelse):

"Nordslesvigeren fra Christiansfeld « giver $\mathrm{i}$ sit bidrag af 8. oktober $i$ den såkaldte "Norddeutsche Zeitung " en ordrig forklaring til forsvar for Christiansfelds direktion, der med sin adresse skulle have fuldbyrdet én Gud velbehagelig gerning til menighedens bedste og derfor var fuldt berettiget. På os jævne nordslesvigere virker den, så vidt vi kender brødremenigheden, ikke indlysende. For at direktionen, om den så bestod af lutter Gabriel'er, skulle have ret til at bede om eller foranledige, at hans majestrt ikke skulle opfylde sit for hele verden afgivne løfte, altså ikke skulle holde sit ord, vil ethvert retsindet menneske benægte. Allermindst vil man vente det af brødremenigheden .... *

Der fulgte en længere række af danskvenlige artikler $i$ Nölnische Zeitung ". I det store og hele bragte de vel nxppe nye momenter $i$ den nationale kamp. Deres opgave var selvfølgelig at gøre det tyske folk bekendt med tilstandene i Sønderjylland og at vakke sympati for sønderjyderne. Også i disse artikler mærker man, at interessen fra brødremenighedens specielle forhold mere og mere går over til de alment sønderjyske. Således omtales de værnepligtiges lod. Det hedder (i oversættelse):

»... Det store flertal af værnepligtige har enten måttet forlade deres hjemstavn, eller de må gå under byrden af en ed, om hvilken de ved, hvor svær den vil være at holde $i$ det afgørende øjeblik af folk, hvis hjerte endnu er bundet til det danske fædreland. De har altid været lykkelige og tilfredse under den milde danske regering, men må nu under den prøjsiske regering ret tydeligt fornemme, at de er stedbørn, en erobret, overvunden, knægtet befolkning, hvis værste fjender, de tidligere augustenborgere, nu som embedsmænd fører et uindskrænket herredømme over dem ....

Ganske morsomt er det at fastslå, at et træk, som vi husker fra den tyske besæettelse $\mathrm{i}$ anden verdenskrig: sammenligningen med Napoleon I's erobring af det tyske land, allerede blev anvendt 1864 i disse artikler $\mathrm{i}$ "Kölnische Zeitung «:

"For at vore tyske medborgere bedre kan forstå vore herværende 
forhold beder vi dem tænke på de tider, da en del af Tyskland var undergivet Napoleons voldsherredømme. $\mathrm{Da}$ blev deres embedsmænd ligeledes stillet over for valget, enten at miste deres vellønnede stillinger eller aflægge troskabseden .... *

Det var næppe på den måde, tyskerne havde ment, at de tidligere elever i Christiansfelds tyske skole skulle gøre brug af deres historieundervisning, hvor Napoleonskrigene havde spillet en stor rolle, og de lå jo kun 50 år tilbage.

I øvrigt har de danske i Christiansfeld ikke alene søgt ved artiklerne $\mathrm{i}$ "Kölnische Zeitung " at vække medfølelse med Sønderjyllands værnepligtige, men de har også været reservisterne behjælpelige med affattelsen af deres protest mod at aflægge faneeden på de lovbefalede kontrolforsamlinger. Et udkast til en sådan protest lyder:

" $\mathrm{Vi}$ undertegnede erklærer herved ikke at kunne give møde på den befalede kontrolforsamling for at aflægge faneeden, fordi kongen af Prøjsens suverænitetsret til hertugdømmet Slesvig er støttet på Prag-freden, hvis artikel V, der lover en fri afstemning i Nordslesvig, endnu ikke er opfyldt, og fordi Wien-traktaten af 1864 hjemler ret til indtil 1870 at bevare vor frihed til at vælge imellem dansk og prøjsisk statsborgerret, hvilken frihed vi ville miste $i$ det øjeblik, vi aflagde faneeden til kongen af Prøjsen.«

\section{Annektionen.}

Prøjsens sejr tvang Østrig til at give afkald på administrationen af hertugdømmerne, og dermed fik prøjserne frie hænder. Man kan ikke sige, at det fremkaldte almindelig glæde. Holstenerne ville have været en selvstændig stat under augustenborgerne. En af deres forende mænd, digteren Theodor Storm, sang:

Berichten mag es die Geschichte, doch keines Dichters froher Mund!

(Lad historien berette det, men ingen digters glade mund!).

Værst føltes det dog naturligvis af de danske i Sønderjylland, da prøjserne annekterede landet. Den 24. januar 1867 blev "Besitzergreifung « højtideligt proklameret på torvet i Haderslev.

Fra denne tid, begyndelsen af 1867, foreligger endnu to udkast

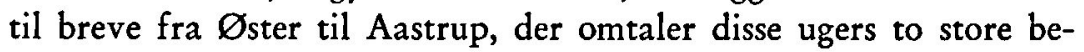


givenheder, annektionen og valget. Det første af disse breve begynder med en undskyldning for, at et brev fra Aastrup af 4 . december ikke er blevet besvaret tidligere. Man må altså gå ud fra, at korrespondancen ikke har været afbrudt i længere tid, men at de mellemliggende breve er gået tabt. I det foreliggende brev hedder det:

"I denne uge har vi jo haft den mærkelige dag, da vi fuldstændig er blevet indlemmet i Prøjsen. I Haderslev har amtmanden på torvet højtideligt proklameret besiddelsestagelsen, som det kaldes, Garve, Jacobsen og Bülow var indbudt til at overvære denne akt. Her $i$ byen blev proklamationer klistret på husene, men da det var en hård blæst, og det regnede, gik de snart løse igen, og der gaves altid hænder, som gerne ville hjælpe til for at få disse sørgelige beviser for, at vi nu virkelig var prøjsere, bort. Hvad der var mig ubehageligst, er, at der i disse proklamationer, som du vel vil se af bladene, ikke nævnes et eneste ord om en forestående afstemning, ligeledes bliver den danske nationalitet slet ikke omtalt som eksisterende, medens netop proklamationernes udfærdigelse på dansk viser, at den er til stede. Det lader til, som om alle løfter om afstemning og tilbagegivelse kun er et tomt mundsvejr for at tilfredsstille Frankrig og den offentlige mening i Europa, men $\mathrm{i}$ virkeligheden vil Prøjsen beholde os. Det er en skammelig ringeagt, der vises os ved forst at love os noget, på papiret give os en ret, men $i$ virkeligheden træde den med fødder. Befolkningen i Nordslesvig har noksom vist, til hvilken side det langt overvejende flertal ønsker at høre, men dog lader regeringen til, som om den ikke vidste noget derom, ja, som til hån hedder det $\mathrm{i}$ proklamationen, at vi kun med modstræben havde tålt vor tidligere forbindelse. Den hele fremgangsmåde har virket nedslående på mig, og jeg tror på befolkningen i almindelighed, men de folk, som skulle være klogere, siger, at sagen går sin regelmrssige gang og skal nok få et godt udfald. Jeg ville ønske det, men jeg frygter, at vi bliver narrede. $\mathrm{Nu}$ forestår os jo nærmest valgene til det nordtyske parlament; her $\mathrm{i}$ vor valgkreds agter vi danske at stemme på Krüger fra Bevtoft, og jeg tvivler ikke om, at vi kunne sætte ham igennem, da alle danske er villige til at give ham deres stemme. Amtmand $\mathrm{Kjer}$ optræder som kandidat for de tysksindede. Her $\mathrm{i}$ byen bliver der vist een af de mindre valgkredse; vi ville kun håbe, at det må bidrage lidt til et for os gunstigt udfald af sagen $i$ det hele. På landet havde de tysksindede sogne- 


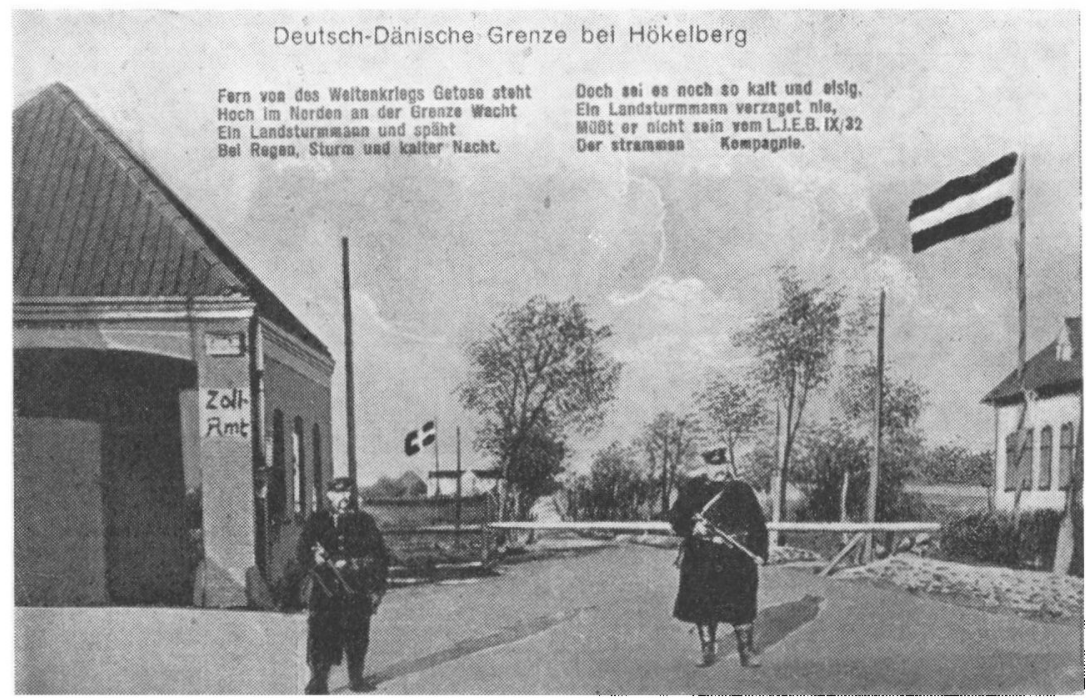

Den dansk-tyske granse efter 1864 to $\mathrm{km}$ nord for Christiansfeld.

fogeder strøget alle deres navne, som var født $\mathrm{i}$ kongeriget. Her $\mathrm{i}$ byen var også en del strøget, men vi har forlangt dem indført igen, men bønderne derimod er $i$ denne tid meget ængstelige. Du spørger i dit brev om forfatteren af artiklerne $i$ "Kölnische Zeitung «, ja, han er mig velbekendt, det er Carl Hansen ${ }^{10}$, hersteds, han har vist sig som en meget god stilist, men det må jo aldeles ikke blive bekendt. Ebbesen ${ }^{10}$ og jeg tager del efter bedste evne, og vi overtaler gerne artiklerne nøje $\mathrm{i}$ forvejen og hører og bedømmer dem, når de er skrevne, førend de bliver afsendt. Der har nemlig været to senere, den sidste om sessionerne, jeg tænker, der snart kommer een til om vores indlemmelse i Prøjsen. Ebbesen navnlig, ønsker også een om vores menighed $\mathrm{i}$ "Kölnische Zeitung «, da han påstår, tyskerne arbejder stærkt $\mathrm{i}$ deres interesse, navnlig er det bekendt, at de har sendt en lykønskning til nytår til kongen af Prøjsen $i$ hele byens navn. Hidindtil har vi ikke gerne villet røre ved vores indbyrdes forhold, da det så let giver anledning til spot og ringeagt mod menigheden fra dens fjenders side. Vi holder også $»$ Kölnische Zeitung ", da redaktionen har leveret særdeles gode artikler om vor sag, og det er det eneste blad, som dog er nogenlunde upartisk. Du 
har vel nok hørt, at Padel ${ }^{10}$ har været $i$ Berlin som medlem af en tysk deputation for at fremstille sin ulykkelige stilling, når det igen blev dansk.

Det var jo at onske, at vor sag snart kom i rigtighed. Den bestandige uvished virker så særdeles nedslående og sløvende på alt, og begge partier gør jo $\mathrm{i}$ en sådan tid alt, hvad de kan, for at virke hver $\mathrm{i}$ sin interesse...

... Jeg ved så meget, at da vi en tid håbede, at det snart skulle blive dansk, da har vi danske opmuntret hinanden til, når det kom så vidt, ikke på nogen måde at fortrædige tyskerne, men søge så meget som muligt at lette dem overgangen. Der ville $j \mathrm{i}$ en sådan tid blive mange vanskeligheder at overvinde, men jeg håber, at Frelseren vil give os nåde til at træffe det rette. Der gives jo blandt de danske også dem, som ville hævne sig, men jeg håber, det kun vil være undtagelser....

Som nævnt i dette brev havde tre af brødremenighedens officielle repræsentanter været til stede på Haderslev torv under annektionserklæringen. Det gav et tysk blad i Nordslesvig anledning til en begejstret omtale af den herskende tyskhed i Christiansfeld. De danskes svar herpå er skrevet på dansk og må altså være blevet offentliggjort $i$ en dansk avis. Det hedder deri:

»Efter beretningen om proklamationshøjtidelighederne i Haderslev hedder det, at der fra mange huse i Christiansfeld vajede det projsiske flag. Foruden to embedsboliger var apoteket det eneste privathus, hvorfra det prøjsiske flag vajede, men ved siden af samme sås et såkaldt slesvig-holstensk. For dette augustenborgernes symbol burde vi dog have været fri på en dag, da Prøjsen erklærede annektionen for fuldbyrdet, og altså alle prætendentens krav ophørte. De mange flag, som »Nordslesvigs Tidende" vil have set, reduceres altså til eet eneste. Tillige meddeler bladet, at en æret deltager fra Christiansfeld tolkede brødremenighedens glæde over nu at tilhøre den store prøjsiske stat. Den ærede gejstlige, som det hedder et andet sted $\mathrm{i}$ bladet, har ingen anden været end pastor Garve. Han er en udlænding, som kun i få år har levet i Slesvig, og har i det højeste ret til at tale i sit eget, men ikke i hele byens navn, hvortil han aldeles ingen fuldmagt havde; tværtimod ville den største del af byens indvånere protesere imod at have en mand til repr $x$ sentant, der som han, ved enhver lejlighed har lagt sin ringeagt for 
alt dansk for dagen. Denne nu til ivrig prøjser omvendte forhenværende augustenborger tager ikke $\mathrm{i}$ betænkning at berede andre vanskeligheder, men forstår nok at undgå byrder for sig og sine, som han nylig har bevist ved på en kløgtig måde at få sin søn fri for den prøjsiske militærtjeneste. Vi antager forholdene, som de er blevet, men hilser dem ikke med glæde. Vi stoler på, at de ord, som grev Bismarck har udtalt i deputeretkammeret i Berlin, er mere værd end borgmester Hansens og herredsfoged Seligs fraser, vi stoler på, at afstemningen vil finde sted, og om sammes udfald har vi jo vel alle, både tyske og danske, kun een mening; den vil vise, at Nordslesvigs befolkning ikke med modstræben har båret den tidligere forbindelse, men at den længes efter at genforenes med det land, hvortil den er knyttet ved fælles nationalitet, fælles sprog og sæder og fælles historie.«

\section{Rigsdagsvalg.}

Ved annektionserklæringen havde de prøjsiske myndigheder og deres mænd haft ordet. Mindre end tre uger senere, den 12. februar 1867, var det landets befolkning, der talte. At det i hele Sønderjylland ville blive en stor dansk sejr, kunne ingen vare $\mathrm{i}$ tvivl om. I Christiansfeld med brødremenighedens talrige tyske embedsmænd var der muligvis nok dem, der håbede på en tysk majoritet, og også blandt de dansksindede sønderjyder har den forestilling gennem årene været herskende, at Christiansfeld altid har været en højborg for tyskheden i Sønderjylland.

Sandt er det naturligvis, at brødremenighedens tyske embedsmænd har villet være tyske. De har rimeligvis også onsket at drage så mange som muligt af menighedsmedlemmerne over på deres parti. Men de danske mænd var på deres post.

Valget til den nordtyske rigsdag den 12. februar 1867 blev da også en klar tilkendegivelse af den danske majoritet indenfor Christiansfelds borgerskab.

Om selve valgresultatet beretter følgende meddelelse, der er skrevet på tysk og derfor utvivlsomt må have hørt til en artikel $\mathrm{i}$ "Kölnische Zeitung «. Der hedder det (i oversættelse):

"At det overvejende flertal af Christiansfelds beboere virkelig slutter sig til den her udtalte opfattelse, viste også valget til den nordtyske rigsdag den 12 . februar, idet $\mathrm{H}$. Krüger, som repræsen- 
terede vor retning, fik 64 stemmer, medens amtmand Kjer, der tilhører den modsatte retning, måtte nøjes med 55 stemmer, og det til trods for, at 8 stemmer af mænd, som har været bosat her i en længere årrække, efter vor mening var blevet slettet imod lovens ordlyd, og desuden 10 danske stemmer var blevet udeladt, medens ikke en eneste tysk stemme manglede. $V i$ er rede til at fremskaffe underskrifter af 80 af vor bys beboere til bekræftelse heraf, og vi håber derfor, at vi er berettigede til at tale $i$ vor bys navn «.

Det følgende brev fra Øster til Aastrup fortæller ligeledes om valget. Det forudsætter, at Aastrup har været bekendt med selve resultatet, men knytter dertil nogle betragninger af mere personlig karakter fra ven til ven. Begyndelsen og slutningen af brevet mangler, men dets væsentligste del turde være bevaret i det følgende:

»Hvad min smule virksomhed for fædrelandets sag angår, så må jeg sige, jeg føler ingen bebrejdelse derover, men jeg kan nok mærke, at jeg er noget forhadt af tyskerne, dog synes mig ikke, at jeg virkelig hader nogen af dem for den sags skyld. Af dit kære brev ser jeg, at du har hørt udfaldet af vores herværende valg; det er dig vel også bekendt, at der var nægtet 8 danske vælgere at stemme, skønt vi i rette tid havde forlangt dem indført, navnene følger. Desuden manglede omtrent 10 andres navne, der var forglemte, at tilføjes listen, så at vi i det hele kunne have fået 18 danske stemmer mere, når det var gået rigtig til. Vi har da også stolet for meget på Lehmann, ${ }^{21}$ men han begynder at blive gammel og er særdeles ængstelig for sin plads. Dagene før valget var i spænding. Da valget var udført, faldt det os ind, at det kunne være godt at underrette Krüger lidt om vores herværende forhold, ifald der skulle blive talt med ham derom af højtstånde folk fra Berlin. Det er jo altid bleven fremhævet fra tysk side, hvor svært det ville være for Christiansfeld, når det igen blev dansk, og vore indsigelser have aldrig kunnet nå derhen. Vi forfattede derfor et skrift, hvori vi fremlagde vor anskuelse om Christiansfelds bestemmelse og vel, Ebbesen og jeg rejste dermed og med en fortegnelse over de fra valget udelukkede til Bevtoft og forklarede Krüger vor mening. Han lovede at medtage skriftet, og hvis der gaves lejlighed, at benytte det. Det var mig særdeles behageligt at gøre hans bekendtskab, dog er det blevet helt stille, da man jo ikke gerne vil gøre unødvendig alarm. På hjemrejsen besøgte vi også Sabroe og havde en meget behagelig 
og interessant samtale med ham. Hvad der nu efter valget bevæger folk mest er den prøjsiske regerings fordring til præsterne at aflægge troskabseden. Der gives endnu omtrent 30 præster, mest $\mathrm{i}$ Tørninglehn, som for samvittighedens skyld ikke kunne aflægge troskabseden, lydighedseden ville de gerne aflægge. Der er nu stor sandsynlighed for, at alle disse vil blive afsat og derved så mange familier komme i den største nød. I vor nærhed vil pastor Hagen i Stepping og pastor Hertel i Moltrup blive ramt af denne skxbne. Pastor Hagen har tænkt på at leje værelser på Fauervraagaard, ${ }^{2 \pi}$ men det er jo svært for en mand med en talrig familie og uden formue således pludselig at blive berøvet alle eksistensmidler. Vi ville håbe, at de danske slesvigere ville skyde sammen, for at de dog kunne få det nødvendigste at leve af. Imidlertid håber vi jo dog endnu, at det ikke kommer så vidt. Der har været en deputation i Berlin for at bede om henstand, indtil afstemningen havde fundet sted. Ved Bismarck kunne de ikke fă audiens og heller ikke ved kongen, men endelig lod kongen dog en embedsmand modtage deres adresse og gav dem derpå det skriftlige svar, at han ikke straks kunne besvare deres andragende, men ville efter forhandlinger med Scheel Plessen ${ }^{23}$ sende dem skriftlig besked, de skulle derfor kun rejse rolig hjem, så længe må præsterne altså også kunne vente. Det var jo ønskeligt, at det hele kunne undgås .... *

\section{De spredte krefter samles.}

Det kan næsten se ud som mere end en ren tilfældighed, at brevene til Aastrup slutter netop her. Dette forste rigsdagsvalg ligesom danner skel mellem to epoker. Hidtil har enkelte grupper stået isoleret, delinger på post, og holdt vagt på deres lille område, hvor det gjaldt om at bevare kontenancen, selv tage ansvaret og initiativet, mange gange med stor snarrådighed. I Christiansfeld med brødremenighedens tyske ledelse kunne det byde på særlige vanskeligheder, og det så meget mere, som det kunne medføre konflikter mellem de nationale og de religiøse hensyn.

Efter valget var situationen i nogen grad forenklet. De enkelte delinger samles $i$ en falles front med en klar ledelse. Tendensen hos de dansksindede $\mathrm{i}$ Christiansfeld, som allerede $\mathrm{i}$ nogen tid havde peget mod tilslutning til andre danske kredse i Sønderjylland, har fået sit afgørende gennembrud. Hvor tidligere de enkelte embeds- 
mandskontorer har været forum for deres klager, bliver det nu rigsdagen, og den rigsdagsmand, der har hele sit vælgerkorps i ryggen, kan gøre det med en ganske anden vægt end den enkelte privatmand. Hvert enkelt spørgsmål bliver del af en helhedsplan, organisationen giver ny styrke, den følger en ensartet taktik. Der er næsten noget symbolsk $i$, at noget af det sidste, brevene beretter, er rejsen til partiets rigsdagsmand $i$ Bevtoft.

Der var stadig mange problemer tilbage. Et af de vigtigste drejede sig om $\S 5$. De mere klartsynede havde nok deres tvivl om dens gennemførelse, men den var dog foreløbig det retsgrundlag, man byggede på. Det var også den, der dannede hovedindholdet af de sidste breve, som her fremlægges.

Tyskerne i hele Sonderjylland gruede naturligvis ved tanken om en mulig folkeafstemning. I efteråret 1867 gik der hårdnakkede rygter om, at brødremenigheden i Christiansfeld havde sendt en deputation til Berlin for at opnå, at dens by skulle blive under tysk herredømme, selv om det øvrige Sønderjylland vendte tilbage til Danmark. Det foranledigede følgende brev fra Ahlmann til Øster:

\section{Gode ven!}

»Augustenborg, den 20. oktober 1867.

Man har jo nyligen læst $\mathrm{i}$ bladene, at en deputation fra Christiansfeld har været $\mathrm{i}$ Berlin for at bede regeringen at drage omsorg for, at denne flække bliver under prøjsisk herredømme og ej tilbagegives Danmark. - Dersom tilstandene hos Dem ikke har forandret sig, siden vi var sammen i Berlin, så må jo majoriteten af Christiansfelds beboere, ja endog majoriteten $i$ brøderemenigheden, være på dansk side, og den nævnte deputation altså ej være berettiget til at udtale et onske, der er stik mod majoritetens. Hvis jeg ikke tager fejl, meddelte De mig i september f. å. i Berlin, at det tyske parti i Deres menighed især består af forstanderskabet, der ved indvandring af $\mathrm{i}$ Tyskland uddannede præster og lærere vedligeholder de tyske anskuelser og antipatien mod danskheden. Det er så naturligt, at De og de fleste $\mathrm{i}$ Christiansfeld fødte har fået kærlighed til deres fødeland, til det land, der har beredt deres forfæedre en god modtagelse, gxstfrihed og frie borgerlige rettigheder, at deres hjerter slår for dette deres fødeland, især under dets trængsler og forurettigelse, og at De ej kunne forene Dem med sådanne, der ville 
hjælpe en fremmed stat $\mathrm{i}$ dens bestræbelser at tilføje os nye krænkelser og hjxlpe den til at slippe fra sine indgangne forpligtelser. Det er netop i denne tid, da man taler om nødvendigheden af garantier for de under dansk scepter levende tyskere, da der sågar er tale om tyske enklaver i det danske land, som Tyskland må beskytte og ej kan afgive til Danmark, at sådanne deputationer og deres ytringer er velkomne for vore modstandere og kunne være til skade for os. De burde derfor ej forblive uimodsagte. Ligesom i det egentlige Danmark boende tyskere forlængst har erklæret, at de $\mathrm{i}$ fuldt mål er betryggede ved de bestående love, at de nyde $i$ høj grad af borgerlig frihed og sikkerhed på person og ejendom, i meninger og tro, således forekommer det mig, ville det være aldeles betimeligt, ja pligt for de christiansfeldere, der har bevaret deres troskab imod fødeland og konge og ikke er utaknemmelige imod beviste velgerninger, dem jo enhver dansk statsborger har modtaget, at fremkomme med en protest mod denne, som jeg formoder, selvkaldede deputations ytringer. - Kan der i Deres by under de nuværende forhold ej tilvejebringes en moderklæring med talrige underskrifter, vil jeg bede Dem om at sende en artikel til et dansk blad, helst til "Fædrelandet ", hvori der oplyses om de sande forhold hos Dem, om at majoriteten ved valgene har været på dansk side, om at deputationen ej udtrykker befolkningens ønske og om, at De ønsker tillige med Deres landsmænd i Nordslesvig at vende tilbage til Danmark. En sådan erklæring ville vist blive påskønnet af den danske regering, og når vi, som jeg vist håber, alle kommer tilbage, vil man vist tage hensyn til christiansfeldernes troskab. At en sådan artikel kan være anonym, er en selvfølge, og De kan ubetinget stole på Plougs diskretion.

Jeg beder Dem, gode ven og kxre landsmand, at overveje denne sag og snarest at gøre noget ved den, når $\mathrm{De}$, som jeg tror, deler mine anskuelser.

\section{Deres N. Ablmann.}

P.S. De kunne jo sende Ploug det andragende, De havde med til Berlin, fra christiansfelderne.«

Det i slutbemærkningen nævnte andragende må være adressen til den prøjsiske konge.

Svaret på dette brev er formentlig af Ahlmann blevet videre- 
sendt til Ploug og på den måde optaget i Det kgl. Biblioteks arkiv som brev til Ploug. Svaret lyder:

Gode ven!

»Christiansfeld, den 23. oktober 1867.

Mange tak for Deres kære brev; det har været mig til stor glæde og opmuntring deraf at kunne se, at De tænker på os og tager del med os her i Christiansfeld. Det er ret mærkeligt, hvor godt tyskerne har forstået at gøre stor alarm af ingenting. En deputation har slet ikke været afsendt herfra, hvis man da under deputation forstår flere personer. En enkelt ung mand, søn af apoteker Padel og provisor på det herværende apotek, har påtaget sig at overbringe en adresse fra en del af de herværende tyskere til Berlin. Flere af de mest ansete tyskere har imidlertid ikke villet befatte dem med denne sag, og forstanderskabet har denne gang holdt sig aldeles udenfor, ja misbilliger endog disse tyskeres adfærd. Alligevel kan man antage, at der må stikke en anden drivfjeder bag disse forsøg på at sætte Christiansfeld $i$ et tysk lys; apoteker Padel har ytret, at opfordringen til dette skridt var kommet fra en så anset og højtstående side, at det ikke kunne undgås at tage hensyn dertil. Om det nu er Rødekro-foreningen eller konrektor Jessen i Haderslev, som måske har bragt denne opfordring med fra Lothar Bucher, det ved vi ikke; men jeg kan dog nxppe tro, at den prøjsiske regering selv skulle have opfordret til disse skridt. Skønt vi ikke tillægger denne rejse stor betydning, har den dog, som De nok kan tænke, berørt os meget ubehageligt, og vi har også søgt at modarbejde sammes indtryk så godt, som vores fattige evne tillod det. Først skrev jeg til forhenværende amtmand Stockfleth ${ }^{24}$ i København, om han ikke kunne underrette den danske regering og sammes befuldmægtigede i Berlin om, at ikke alene den danske majoritet, men også forstanderskabet og flere ansete tyskere ikke billigede denne adresses afsendelse. Vi ønsker tværtimod jo før jo hellere at forenes med Danmark, dette er et livsspørgsmål for vores by, og både dens materielle og åndelige bestån og fremvækst er afhængig deraf. Samtidig afsendte guldsmed Ebbesen ${ }^{10}$ en lignende skrivelse til Krüger $\mathrm{i}$ Berlin med bøn om at benytte den så godt som mulig. I fredags passerede d'herrer Sabroe og Salicat her igennem til Kolding, og da vi traf dem, meddelte vi dem sammenhængen og bad dem fra Kol- 
ding straks at telegrafere til "Berlingske Tidende « for at gendrive det første usande telegram. ${ }^{*}$ Vi har desuden skrevet en temmelig udførlig artikel til "Kölnische Zeitung «, som De vistnok snart selv vil kunne få lejlighed til at læse, og hvori vore forhold så godt som muligt og netop i den ånd, som De mener, bliver oplyst. Deres forslag om $i$ lighed med, hvad der er sket $i$ kongeriget af de der boende tyskere, at offentliggøre en erklæring, at vi havde haft det godt under den danske regering og ønskede uden nogen som helst garanti eller forbehold at vende tilbage til den, har varet mig ret indlysende, og hvis vi kunne vente et antageligt antal underskrifter, ønskede vi også gerne at udføre dette forslag, men for øjeblikket antager jeg, at vi ikke kunne sætte det igennem. Forstanderskabets reserverede og endog velvillige holdning (de tror nu fast, at det bliver dansk her alligevel) pålægger os den forpligtelse også at holde lidt tilbage. En del ellers meget gode danske har en stor modbydelighed for at træde offentligt frem med deres navnes underskrift; det er jo også lidt anderledes her end med tyskerne $i$ kongeriget, disse bliver støttet og styrket $i$ at bekende sandheden, såvel ved deres medborgere som ved den bestående regering. Vi derimod måtte træde $\mathrm{i}$ opposition med en del af vore medborgere og med den bestående regering. Sandt nok, man skulle dog bekende sandheden, og hvis det kun kom an på mig og enkelte ligesindede, ville det også ske, men det kan ikke undgås at tage hensyn til ængstelige gemytter, når de således som her danner flertallet. Dog kan De være forvisset om, at jeg nok skal have det $\mathrm{i}$ tanker, og det kunne jo hænde sig, at der indtraf forhold, hvor en sådan gendrivelse var aldeles nødvendig, og da skal den ikke blive forsømt. Deres forslag om at skrive en artikel til "Fædrelandet" har vi straks antaget, en sådan er $\mathrm{i}$ arbejde enten til dette eller til et andet københavnsk blad.

Deres kære brev var skrevet ganske således, som mine tanker og anskuelser er; ja, det er sandt, $i$ trængselens og modgangens dage viser kærligheden til fædrelandet sig allertydeligst. Vi ville enige og udholdende slutte os sammen og hver i sin kreds gøre alt, hvad vi kunne, for at målet, genforeningen med vort elskede fædreland, gamle Danmark, kan nås. Men vi ville heller ikke glemme at bede Herren om at give sin velsignelse til vore bestræbelser og lade dem lykkes. Imidlertid holder vi jo fast $\mathrm{i}$ håbet, at denne tid skal komme og helst komme snart. Endnu engang mange tak for Deres kære 
brev; hvis det var Dem muligt atter engang at skrive mig til, beder jeg Dem om at gøre det.

De hilses på det venskabeligste fra Deres hengivne

A. Øster.*

Brevet til Stockfleth lyder således:

"Herr kammerherre W. W. v. Stockfleth, commandeur af Dannebrog og dannebrogsmand.

Opmuntret ved den velvilje og deltagelse, som Deres højvelbårenhed stedse har vist vor by, tillader vi os atter at henlede Deres opmærksomhed på vore forhold.

Med en til vished grænsende sandsynlighed havde vi erfaret, at der i disse dage er blevet foretaget skridt af det tyske parti her, og sandsynligvis også i Haderslev, for atter at indvirke på den prøjsiske regering og søge at forhindre, at vor by bliver givet tilbage til Danmark, navnlig skal apoteker Padel, hersteds, have modtaget opfordring om at sætte alt i bevægelse i dette øjemed. Forstanderskabet tager denne gang ingen del $\mathrm{i}$ disse skridt, og det tyske parti her $\mathrm{i}$ byen er ikke talrigt, som det sidste valg jo atter har vist, så at man vel kan håbe, at sligt ikke vil kunne have indflydelse på underhandlingernes gang. Alligevel kan man befrygte, at enhver udtalelse fra denne side vil blive taget til indtæegt af den projsiske regering. Genforeningen med Danmark er det inderligste ønske af det langt overvejende flertal af byens beboere, den er et livsspørgsmål for vor by, hvis materielle og åndelige bestån og fremvækst er afhængig deraf, derfor har vi ment at burde underrette Deres højvelbårenhed om, at enkelte personer ved en til den prøjsiske regering indsendt adresse søger at forhindre den, og vi håber, at De vil være os behjelpelig ved at modvirke en sådan adresse. Vi overlader det ganske til Deres skøn, om der kan eller bør gøres noget for, at den danske regering eller sammes befuldmægtigede kan vise, hvor stridende imod befolkningens ønsker og interesser en sådan adresse er.

Sluttelig beder vi at modtage disse linjer som et tegn på den tillid, vi har til Deres højvelbårenhed, der bedre end vi kan gennemskue forholdene, og vi anmoder Dem om også $i$ fremtiden at beholde os og vor by $i$ velvillig erindring.

Vi forbliver med særdeles højagtelse Deres hengivne«

(Underskrift mangler) 
Denne lille samlings sidste brev, der så godt som sikkert er rettet til Ahlmann, har ganske vist ingen praktisk betydning fået. Det skal dog for fuldstændighedens skyld tages med, og det kan vel også være et vidnesbyrd om de danskes årvågenhed, samtidigt med at der endnu lyder en tone igennem fra planerne om købet af Volstrupgård.

Gode ven!

»Christiansfeld, den 25 . august 1869.

I de sidste dage har jeg ikke kunnet komme bort fra den tanke, at det netop nu var den rette tid til, at nordslesvigerne gennem deres valgte repræsentanter burde henvende sig til kejseren af Østrig med bøn om, at han vil påskynde eller $\mathrm{i}$ det mindste påtale udførelsen af den femte paragraf af Prag-freden. Der hersker $i$ denne tid en del spæending mellem Wien og Berlin, så at jeg antager, at en deputation herfra ville blive vel anset og modtaget $\mathrm{i}$ Wien. I den forordning, der under tugthusstraf forbyder befolkningen at henvende sig til fremmede souverainer, bliver kejseren af Østrig, som dengang var medejer af hertugdømmerne undtagen, og jeg er derfor af den formening, at det også endnu må være tilladt at henvende sig til ham. Desforuden nærmer det $\mathrm{i}$ Wien-freden bestemte tidsrum af 6 år sig sit udløb. Under trykket af de store ulykker, der i 1864 overgik vort kære fædreland, modtog mange indbyggere $\mathrm{i}$ hertugdømmerne med glæde det løfte, at vi i 6 år måtte beholde indfødsret i Danmark og have frihed til uhindret at flytte derhen, [hvis vi] besluttede inden den tid at flytte til vort gamle fædreland; men imidlertid indtraf de begivenheder, der afsluttedes med Prag-freden, der åbnede slesvigerne en grundet udsigt til, at alle de, som ønskede det, kunne vende tilbage til Danmark, og derfor blev vi roligt, hvor vi var. Hvis kejseren af Østrig, som efter Bismarcks udsagn er den eneste, der har nogen ret til at tale med om Prag-fredens udførelse, ikke vil gøre sin indflydelse gældende, er der slet ingen udsigt til, at den prøjsiske regering vil gøre alvor af udførelse af $₫ 5$, og imidlertid lever befolkningen i Nordslesvig under fremmedherredømmets materielle og åndelige tryk, hvorfra netop Prag-fredens 5. artikel skulle udfri os.«

Nogen egentlig praktisk betydning fik forslaget om en deputation til Wien ganske vist ikke, men spørgsmålet er dog snart efter blevet 
drøftet indgående. Krüger var for tanken, og med ham mange andre. Ahlmann var imod den, og han fik medhold fra Orla Lehmann. Den blev derfor skrinlagt. Men den vidner $i$ hvert fald om, at de danske $\mathrm{i}$ Christiansfeld fulgte årvågent med $\mathrm{i}$ tidens udvikling, og det kan være værd at lægge mærke til, at denne udpræget antiprojsiske tilkendegivelse muligvis var udgået og $\mathrm{i}$ det mindste har fået stærk genklang $\mathrm{i} \gg t y s k e r r e d e n «$ Christiansfeld.

\section{Afslutning.}

Årene, der fulgte, var svære for de danske i Christiansfeld. De kæmpede på en dobbelt front. Under vægten af den tyske stormagts vælde forskød styrkeforholdet sig til tyskernes fordel. Hvad de gamle, danske stridsmænd havde håbet og kæmpet for, at dannebrog på ny skulle gå til tops $\mathrm{i}$ Christiansfeld, oplevede ingen af dem, men de holdt trofast ud, indtil døden endte deres kamp.

Den sidste af dem skrev i 1903-1904 et par breve til Ludvig Schrøder $\mathrm{i}$ Askov, som dennes søn velvilligst har stillet til rådighed.

Min fader skriver da 3-4 år før sin død:

»Som født medlem af brødremenigheden holder jeg meget af den, anerkender dens grundsætninger og beundrer Herrens førelser med den såvel $\mathrm{i}$ den gamle som $\mathrm{i}$ den nyere tid. På den anden side er jeg en dansk mand, født her i Sønderjylland af danske, nørrejyske forzldre, og deler de nationale og patriotiske følelser og anskuelser med alle danske nordslesvigere. $\mathrm{Da}$ brødremenigheden har sit hoveds $x$ de i Tyskland, og dets fleste medlemmer er tyskere, så kan det ikke undgås, at der blandt dem findes folk, der lader det nationale gå frem for det kristelige. Disse lægger jo særskilt vægt på, at vi skal være øvrigheden lydige, og at vi skal opgive enhver tanke og ethvert håb om at blive genforenede med vort gamle fædreland. I den danske tid har vi også fremhævet lydighed og troskab mod kongen, men dengang syntes den os også mere berettiget, når det gælder vor gamle nedarvede landsherre, end nu, da det gælder en fremmed erobrer, der har forenet os med sit rige imod vor vilje. Det har derfor været mig kært, at en af vore biskopper, der visiterede her i september måned, i sin afskedstale fremhævede, at ligesom det var en fare for menigheden i Christiansfeld, at den bestod af to nationaliteter, således var det også dens hverv og en prøve på dens xgthed, at den kunne vise, hvorledes kristne, om de også tilhører forskellige 


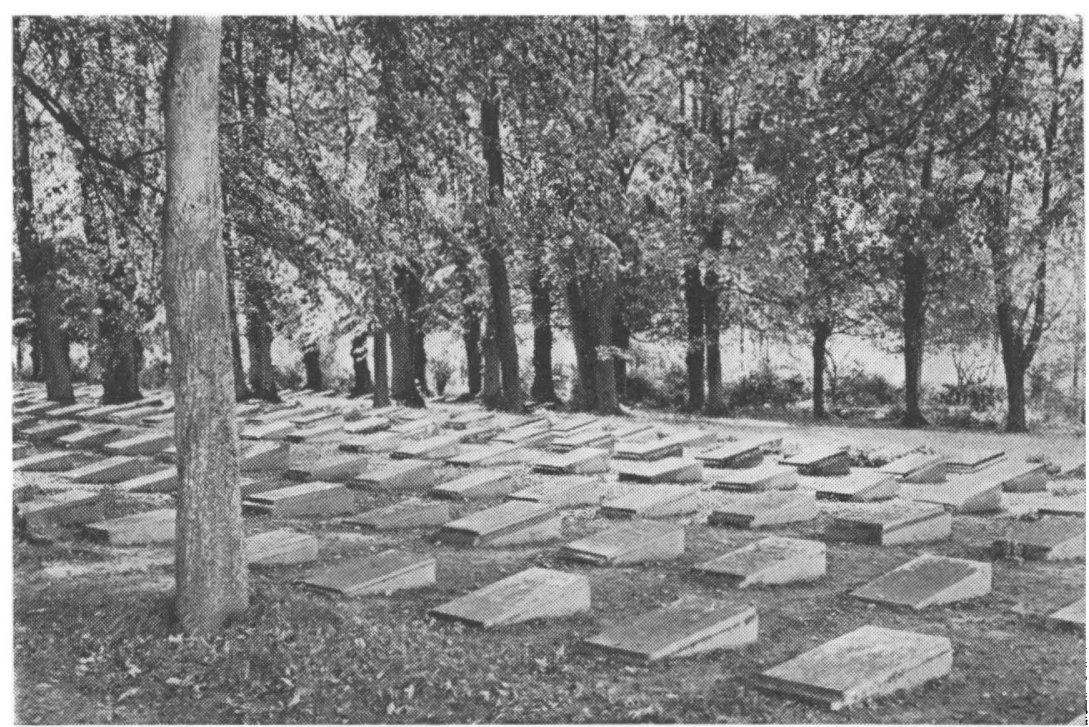

„Gottesacker", Christiansfelds kirkegård, hvor Oster og de fleste af hans meningsfaller ligger begravet.

og hinanden bekæmpende nationaliteter, dog kunne leve fredeligt og kærligt sammen, når kristendommen er hovedsagen. Derom er det jo, det gælder, og vi må desværre tilstå, at der på begge sider findes folk, der ikke er sande Guds børn. Men vi må dog takke Gud derfor, at der endnu, navnlig blandt den danske del, findes et flertal af alvorlige kristne...

... Det er mangen gang svært nok at tage alt med ro og i ydmyghed, men vi ville dog håbe, at når Herrens time kommer, vil han igen oprejse os. Jeg kommer vel nxppe til at opleve den tid, da jeg allerede er 75 år gammel, men jeg håber dog, at tiden vil komme. For os alle bliver det jo hovedsagen at gå salig hjem til Frelseren, når dødens time kommer, og kunne vi hos ham have vort evige uforstyrrede hjem, så gør det jo ikke noget, om vi hernede har følt os som fremmede og udlændinge ...

Deres inderlig hengivne $A$. Øster.* 


\section{NOTER}

1. Da Østrig og Prøjsen efter Wiener-freden overtog regimet $i$ hertugdømmerne, blev de danske regeringsembedsmænd erstattet af tyske. De fleste af dem var *augustenborgere*, der ønskede at oprette en selvstændig delstat *SchleswigHolstein* indenfor det tyske rige. Disse tysksindede embedsmænd, der under det danske styre fra 1850 til 1864 mente sig forurettet, agtede nu at hævne sig på den dansksindede befolkning til trods for en bestemmelse $\mathrm{i}$ Wienerfreden om, at ingen måtte forfølges for sit politiske sindclag. Til denne gruppe hørte de i det følgende nævnte herredsfogeder Andersen og Selig i Tyrstrup samt disses nærmeste foresatte, amtmand Kjer i Haderslev. Denne var igen undergivet *Landesregierung*, hvis *Civilkommission* alene var berettiget til at afsætte tidligere danske embedsmænd, særlig præster. Formanden for Civilkommission* var friherre von Zedlitz, der $i$ alt fald $i$ begyndelsen synes at have bestræbt sig på at dømme mere upartisk.

2. Leopold Garve, som var tysk præst i Christiansfeld, var kommet dertil 2. november 1852 fra Neusalz, en herrnhutisk koloni i Schlesien. Han døde ifølge Aeltesten Conferenz' protokol pludselig i Christiansfeld den 20. august 1867 ved "Nervenschlag*.

Herredsfoged William Christian Andersen var fadt i Christiansfeld (27. 3. 1816), hvorfor amtmand Kier anså ham for særlig sagkyndig. Han var ikke medlem af brødremenigheden; udpraget tysksindet. Han døde 15. december 1864 .

Herredsfoged Selig (født 13. 1. 1833 i Haderslev) var cand. jur. og fra 1865 til 67 Andersens efterfølger som herredsfoged i Tyrstrup.

Otto Detlev Harald Kjer (født i Haderslev 1823) havde studeret retsvidenskab i Kiel og deltaget $\mathrm{i}$ oprøret 1848 som løjtnant. 1864 blev han konstitueret som amtmand i Haderslev.

Octavio Athanis von Zedlitz (født i Glatz, Schlesien 1840) blev allerede 7. 2. 1864 indsat som prøjsisk civilkommissær med sæde i Flensborg.

3. Joseph Aastrup synes at være fodt i Christiansfeld, hvor han senere blev lærer ved brodremenighedens skole. Derfra blev han i maj 1859 forflyttet til den herrnhutiske koloni i Neudietendorf i Thüringen, hvor han virkede som $*$ Brüderpfleger*, en slags kapellan, indtil han $i$ juli 1862 vendte tilbage til Christiansfeld og overtog embedet som dansk præst samtidig med, at han tog sig af menighedens venner $i$ omegnen.

4. Christiansfeld hørte under den $*$ Tyske Brødre Unitet*. Dennes øverste myndighed var en synode, som var valgt af de enkelte kolonier og plejede at træde sammen hvert andet år. Denne synode sluttede med en $₫$ Synodalerlass*, der angav retningslinjerne. Efter disse skulle »Unitäts Aeltesten Conferenz* (U. A. C.), som blev valgt af synoden, $i$ de kommende to år lede brodremenigheden. U. A. C. bestod af flere fagafdelinger, der bl. a. udnævnte de enkelte menigheders embedsmænd. Desuden havde hver menighed sin »decernent i U. A. C., der i vigtige sporgsmål havde en afgørende betydning.

I den enkelte herrnhutiske koloni var ledelsen betroet til en Aeltesten Conferenz* under forsæde af præsten, og den tog sig af de kirkelige opgaver. De mere administrative anliggender var overladt til "Aufseher Collegium* under forstanderens forsæde. I mere betydningsfulde sager krævedes et snæ- 
vert samarbejde af disse to korporationer. I princippet var forfatningen altså særdeles demokratisk. I praksis kunne den dog virke temmelig autoritær.

5. Foruden Aastrup var også bestyreren af brodremenighedens forretning Spielwerg \& Co., Christian Gormsen, af de tyske myndigheder beskyldt for tyskfjendtlighed. I dette tilfælde nøjedes U. A. C. dog med en alvorlig irettesættelse. Chr. Gormsen var ligeledes medlem af $\times$ Aeltesten Conferenz $\ll$.

6. Som Christiansfelds tyske præst skulle Garve sende beretninger om forholdene $\mathrm{i}$ menigheden til styrelsen i Berthelsdorf. Der hentydes i det danske brev til, at disse beretninger har været præget af misundelse mod Aastrup, hvis prædikener var meget bedre besøgt end Garves.

7. Den i det følgende anførte korrespondance mellem Garve, resp. U. A. C. og de verdslige myndigheder eller kladderne dertil, er velvilligst blevet stillet til min rådighed af landsarkivet i Ảbenrå.

8. Navnet Matthiesen tyder på, at manden var af dansk æt. Han havde imidlertid fået sin uddannelse ved herrnhuternes tyske institutter og var åbenbart blevet fortysket. Han beherskede dog stadig det danske sprog så vidt, at han kunne forstå det uden tolk.

9. Med »fjenden « er ment »den onde fjende djæevelen «.

10. De $\mathrm{i}$ de følgende breve til Aastrup nævnte medlemmer af brødremenigheden i Christiansfeld har naturligvis været kendt for Aastrup, men udover deres nationale stillingtagen har de næppe gjort sig særlig bemærket $\mathrm{i}$ menighedslivet. Bortset fra de tyskfødte herrnhutiske embedsmænd er kun Padel og Süberkrüb nævnt som tilhørende det tyske parti. Dansksindet var:

Christoph, Sigmund, snedkermester i Christiansfeld. Skønt slægten var af tysk oprindelse, var han som alderspræsident det danske partis officielle representant.

Bank, ivrig dansk, havde afhæendet sin gård i Jylland for at flytte til Christiansfeld. Han gik senere over til »bornholmerne $\alpha$.

Ebbesen, Christophs svigersøn, urmager og guldsmed, horte til de mest aktive forkæmpere for den danske sag.

Gormsen, Chr., senere ridder af dannebrog, var leder af brødremenighedens forretning Spielwerg \& Co. På grund af sin udsatte stilling måtte han trods sit danske sindelag holde sig tilbage $\mathrm{i}$ den nationale kamp.

Grøndahl, Mads, var køkkenchef $\mathrm{i}$ »brødrehuset «, indtil han blev stævnet for retten, fordi han havde fornærmet en tysk embedsmand. I stedet for at efterkomme stævningen, flygtede han over grænsen til Danmark, men vendte kort efter tilbage til Christiansfeld for at stille sig til sin straf. »Aeltesten Conferenz* afsatte ham fra hans stilling, hvorefter han åbnede en bagerforretning i Christiansfeld.

Hansen, Carl, gift med én af Christophs døtre, var købmand. Han havde i nogen tid opholdt sig i Altona, hvorfor han gjaldt for særlig tyskkyndig. Han forfattede artiklerne til «ölnische Zeitung «. Senere var han på tale som Chr. Gormsens efterfølger i ledelsen af Spielwerg \& Co., men blev vraget for sin danskheds skyld.

Kaftan og Wolff, to unge mænd, blev efter U.A.C.s udtrykkelige ønske udelukket af menigheden efter et meget ungdommeligt sammenstød med det tyske gendarmeri. 
11. Adolf von Hohenlohe-Ingelfingen blev af den prøjsiske regering indsat til at undersøge de overgreb, som augustenborgske embedsmand straks efter Wiener-freden havde begået. Det var et led i modsætningen mellem Prøjsen og Østrig, der favoriserede augustenborgerne. Sammen med Zedlitz fo'r Hohenlohe hårdt frem mod dem til de danskes glæde, hvilket dog blev af kort varighed. Episoden bidrog imidlertid til en skærpelse af modsætningen mellem Prøjsen og Østrig, der $\mathrm{i}$ overenskomsten $\mathrm{i}$ Gastein af 15 . august 1865 foreløbig blev udjæevnet, men senere førte til den prøjsisk-østrigske krig 1866.

12. Theodor Sabroe var ivrig dansksindet boghandler og sparekassebogholder $\mathrm{i}$ Haderslev. Hans søn Axel Vilhelm Theodor Sabro udgav senere *Modersmaalet $\star$ i Haderslev.

13. Friis, ejeren af gården Ejsbøl lige udenfor Haderslev, hørte med til danskhedens ledende reprasentanter.

14. Det drejer sig formentlig om herrnhutisk påvirkede jyder, som regelmæssigt blev besøgt af herrnhutiske udsendinge ( $*$ Disporaarbeiter $*$ ).

15. Ernst Reichel var herrnhutisk teolog, havde $\mathrm{i}$ sine yngre år været $*$ Brüderpfleger i Christiansfeld. Efter at han senere var blevet indvalgt i U. A. C., havde han en tid været *decernent for Christiansfeld.

16. Tysksindede medlemmer af brødremenigheden angav deres dansksindede - medbrødre* for det tyske gendarmeri og forlangte, at de blev idømt de hårdeste straffe.

17. Gemeinrat var et møde af alle menighedens voksne medlemmer, hvor man altså kunne vente dansk majoritet.

18. "Die Väter « var $\mathrm{i}$ daglig tale betegnelsen for medlemmerne af U. A.C.

19. Både den projsiske konge og Bismarck nægtede at modtage adressen.

20. Artiklerne $\mathrm{i}$ *Kölnische Zeitung* er kendt som et led $\mathrm{i}$ sønderjydernes nationale kamp, men det har næppe varet almindelig kendt, at de, eller $i$ hvert fald en del af dem, stammede fra Christiansfeld.

21. Lehmann var oprindelig skræddermester. Han var allerede $i$ den danske tid blevet udnæunt til official* og har vel frygtet for at blive afsat af de tyske myndigheder, hvis han ikke makkede ret.

22. Fauervraagaard havde tilhert kammerherreinde Holstein, som havde testamenteret gården til brodremenigheden Christiansfeld.

23. Scheel Plessen var født i Kiel, havde før 1864 været $i$ dansk tjeneste, men stod $\mathrm{i}$ opposition til regeringen og sluttede sig hurtigt til det prøjsiske parti. Han blev overpresident for Slesvig-Holsten.

24. Stockfleth var den sidste danske amtmand i Haderslev, hvorfra han efter 1864 flyttede til København.

25. Telegrammet har formodentligt indeholdt meddelelsen om deputationen * fra Christiansfeld. 